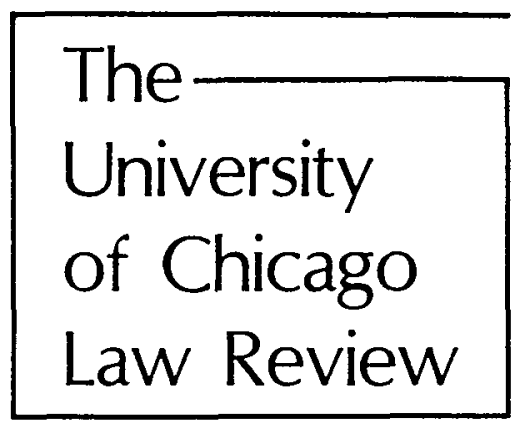

1990 by The University of Chicago

\title{
Levels of Generality in the Definition of Rights
}

\author{
Laurence H. Tribe $\dagger$ and Michael C. Dorf $\dagger \dagger$
}

\section{INTRODUCTION}

This article focuses on one important aspect of the quest for constitutional meaning: how to determine whether a particular liberty-whether or not expressly enumerated in the Bill of Rights-is a "fundamental" right. Whether under the somewhat tarnished banner of substantive due process or under a different rubric, the designation of a right as fundamental requires that the state offer a compelling justification for limitations of that right. ${ }^{1}$ In addition, under the Equal Protection Clause of the Fourteenth Amendment, state-sanctioned inequalities that bear upon the exercise of a fundamental right will be upheld only if they serve a compelling governmental interest. ${ }^{2}$ Because the "strict" scrutiny which applies to laws that affect fundamental rights in either of these two ways is usually "fatal," whether to designate a right as fundamen-

$\dagger$ Tyler Professor of Constitutional Law, Harvard Law School.

t† Law Clerk to Judge Stephen Reinhardt of the United States Court of Appeals for the Ninth Circuit.

${ }^{2}$ See, for example, Moore $v$ City of East Cleveland, 431 US 494, 500-06 (1977); Griswold $v$ Connecticut, 381 US 479 (1965).

2 See, for example, Sosna v Iowa, 419 US 393, 406-07 (1975); Loving $v$ Virginia, 388 US 1, 11-12 (1967).

${ }^{3}$ Gerald Gunther, Foreword: In Search of Evolving Doctrine on a Changing Court: A 
tal poses a central substantive question in modern constitutional law.

How should the Court determine if an asserted right is fundamental? Even when prior cases explicitly designate a right in those terms, limitations of space as well as the institutional limitations embodied in Article III's case or controversy requirement will mean that those prior cases have not spelled out the precise contours of the right. The question then becomes: at what level of generality should the Court describe the right previously protected and the right currently claimed? The more abstractly one states the already-protected right, the more likely it becomes that the claimed right will fall within its protection. For instance, did the Court in Griswold $v$ Connecticut ${ }^{4}$ recognize the narrow right to use contraception or the broader right to make a variety of procreative decisions? Obviously, the descriptive choice will affect the Court's decisions in other cases, such as those involving abortion.

The selection of a level of generality necessarily involves value choices. But in the case of Michael H. $v$ Gerald D., ${ }^{5}$ Justice Scalia, writing for himself and Chief Justice Rehnquist, suggested that he had discovered a value-neutral method of selecting the appropriate level of generality. That method, he wrote, is to examine "the most specific level at which a relevant tradition protecting, or denying protection to, the asserted right can be identified." Justice Scalia implied that any other method is arbitrary. ${ }^{7}$

This essay challenges Justice Scalia's formulation of the levels of generality problem. In Part I we locate the problem within the larger context of constitutional interpretation generally. Using illustrations drawn from cases that involve the interpretation of enumerated as well as unenumerated liberties, we argue that any meaningful theory of constitutional interpretation must rely to a considerable degree on extra-constitutional sources. In Part II we

\footnotetext{
Model for a Newer Equal Protection, 86 Harv L Rev 1, 8 (1972) (making this observation with respect to equal protection strict scrutiny). But see Austin v Michigan, $110 \mathrm{~S} \mathrm{Ct} 1391$ (1990) (Michigan statute which forbade corporations from spending general funds on statewide election campaigns was justified by a compelling state interest); Cleburne v Cleburne Living Center, Inc., 473 US 432, 442 (1985) (conversely, finding an equal protection violation in discrimination against the mentally retarded while claiming not to be applying strict scrutiny).

381 US 479 (1965).

- 109 S Ct 2333 (1989).

${ }^{B}$ Id at $2344 \mathrm{n} 6$.

' Id (contending that "the dissent has no basis for the level of generality it would select").
} 
offer Bowers $v$ Hardwick ${ }^{8}$ as an example of how different justices can reach radically different conclusions about the appropriate characterization of prior cases. Based on a strategy suggested by Justice Harlan's dissent in Poe v Ullman, ${ }^{9}$ we then sketch one approach that can guide judges in selecting a level of generality.

In an attempt to determine whether anything about the levels of generality problem is unique to legal interpretation, in Parts III and IV we look to literature and mathematics, respectively. These excursions confirm the conclusion of Part I: logical consistency with what has come before is too weak a condition to determine what must come next. A work of literature may have more than one "correct" ending, mathematical systems may proceed from different unprovable postulates, and a line of constitutional decisions may fit accurately within more than one abstraction.

Using the insights gained from our general treatment of the problem, in Part $V$ we evaluate Justice Scalia's suggestion in Michael $H$. We conclude that Justice Scalia's proposal is inadequate. Far from providing judges with a value-neutral means for characterizing rights, it provides instead a method for disguising the importation of values. Having reached the unsurprising conclusion that to designate a right as fundamental requires value judgments, in Part VI we dispute Justice Scalia's charge that such judgments are necessarily arbitrary. We advance a theory of constitutional interpretation that takes as its point of departure Justice Harlan's observation in Poe that the search for unenumerated rights should proceed by interpolation and extrapolation from the enumerated rights. Applying this method not just to the clauses of the Bill of Rights but also to the Supreme Court's precedents, we argue that a typical judicial opinion distinguishes between essential and non-essential facts, and that by paying attention to such distinctions, judges trained in the method of the common law can generalize from prior cases without merely imposing their own values.

\section{Constitutional Interpretation in the Post-Lochner Era}

Since it repudiated the use of substantive due process as a basis for protecting economic rights, ${ }^{10}$ the Supreme Court has struggled to find a firm foundation for other rights not explicitly

848 US 186 (1986).

- 367 US 497, 522 (1961) (Harlan dissenting).

so See West Coast Hotel v Parrish, 300 US 379 (1937). 
delineated in the constitutional text. If, as Justice Holmes put it in his famous Lochner dissent, "a constitution is not intended to embody a particular economic theory,"11 why then should the Constitution embody a particular theory of personhood, as it apparently must if we are to make sense of the claim that the word "liberty" in the Due Process Clause encompasses the autonomy to decide whether, for example, to engage in sexual intercourse without the risk of bearing a child?

Why is the liberty to decide whether to carry a pregnancy to term more fundamental than the liberty to work for less than four dollars per hour? We cannot answer this question-and others like it-without recourse to values at least partly external to the constitutional text. The Constitution does not explicitly mention either liberty. The value system that prefers the former liberty to the latter may be common among judges or even in society at large, but that system is still external to the literal text of the Constitution. ${ }^{12}$

To some, the need for value judgments renders the entire exercise of protecting unenumerated rights illegitimate. Robert Bork, for example, has written that the true meaning of Justice Stone's famous footnote four ${ }^{13}$ is "that the Justices will read into the Constitution their own subjective sympathies and social preferences."14 Bork is correct in a limited sense: because the justices of the Supreme Court are human, they cannot isolate themselves from the sympathies that move them, and society shapes those irreducibly subjective sympathies.

However, to recognize the limits of human objectivity does not require that we abandon the effort to approximate those limits. Taken seriously, Bork's view implies that the Court should uphold virtually no claim of constitutional right-enumerated or unenumerated. For in any given case the putative right-holder claims that the Constitution protects her specific conduct, although the Constitution's text inevitably will not describe the details of that conduct.

"Lochner $v$ New York, 198 US 45, 75 (1905) (Holmes dissenting).

12 Compare Laurence H. Tribe, American Constitutional Law § 8-7 at 581-86 (Foundation, $2 \mathrm{~d}$ ed 1988) (the Court could have rejected Lochner on the ground that the legislature made the wrong substantive choice about what liberties to protect, rather than on the ground that the Court was institutionally incompetent to make the substantive choice).

${ }^{23}$ United States v Carolene Products Co., 304 US 144, 152 n 4 (1938) ("Nor need we enquire whether ... prejudice against discrete and insular minorities may be a special condition, which . . . may call for a correspondingly more searching inquiry.").

${ }^{14}$ Robert H. Bork, The Tempting of America 61 (Macmillan, 1990). 
For example, the Sixth Amendment guarantees a criminal defendant's right to a "speedy" trial. Suppose that because of docket crowding Jones, unable to post bail, languishes in jail for three years before his murder trial. Has the state denied Jones his constitutional right to a speedy trial? If the Court so holds, Bork's view implies that the Court has created a right. The Sixth Amendment, after all, does not enumerate the right to a trial in less than three years. How is the judgment that three years (or three decades, or three months) is not "speedy" any less subjective than the judgment that the right to have sex without children is part of the "liberty" protected by the Fourteenth Amendment?

In an attempt to answer questions like this, Bork contrasts the judicial enterprise of categorizing fundamental rights included within the term liberty with that of delineating the boundaries of the rights enumerated in the Bill of Rights. The former enterprise, because it employs such formulae as "deeply rooted in this $\mathrm{Na}$ tion's history and tradition,"15 he labels "pretty vaporous stuff."16 However, the line-drawing necessary to interpret the Bill of Rights, according to Bork, "starts from a solid base, the guarantee of freedom of speech, of freedom from unreasonable searches and seizures, and the like."17 Bork does not explain why the words "speech" and "unreasonable" are any more "solid" than the word "liberty" or than the formulae that Bork dismisses as vaporous.

Some have argued that the specification of various liberties in the Bill of Rights requires the Court to play a greater role in determining the substantive content of enumerated rights than of unenumerated rights, ${ }^{18}$ although this contention seems impossible to square with the command of the Ninth Amendment. But even if we were to accept the premise that enumerated rights are more important than unenumerated rights, that does not mean that the process of defining the boundaries of the enumerated rights is any less subjective an enterprise than that of determining what liberties are fundamental. Because the issues of interpretation that arise in construing the words of the Bill of Rights are identical to those that arise in the fundamental rights context, throughout this article we borrow examples that involve the enumerated rights to illuminate the search for unenumerated rights.

1s Moore, 431 US at 503.

16 Bork, The Tempting of America at 118 (cited in note 14).

17 Id.

${ }^{18}$ See, for example, Griswold, 381 US at 525-26 (Black dissenting) (" to pass upon the constitutionality of statutes by looking to the particular standards enumerated in the Bill of Rights and other parts of the Constitution is one thing; to invalidate statutes because of application of "natural law" deemed to be above and undefined by the Constitution is another." (quoting Adamson v California, 332 US 46, 90-92 (1947)). 
Perhaps, then, the Constitution protects neither the right to have sex without children nor the right to a criminal trial within three years of indictment. Would it reduce the Constitution to a nullity to say that the courts may strike down only flat contradictions of its literal terms? At times, it's true, cases arise in which constitutional rights may be defined as the mirror images of the text's express prohibitions. Consider the remarkable city ordinance in Board of Airport Comm'rs for the City of Los Angeles $v$ Jews for Jesus, Inc., ${ }^{19}$ which banned "all First Amendment activities" in the Los Angeles airport. Unsurprisingly, the Supreme Court held that the ordinance contravened the First Amendment. But if we require truly literal contradictions of the Constitution's terms, even the Los Angeles ordinance could be viewed as constitutional. It did not, after all, purport to ban all "speech," but only those "First Amendment activities" that take place in the Los Angeles airport. And it was not an enactment of Congress, which alone is expressly bound by the First Amendment's prohibitions. One can hardly imagine a statute whose judicial invalidation is truly compelled by the literal terms of the Constitution. Perhaps the literalist would strike down an Act of Congress that made every exercise of "the freedom of speech" punishable by a federal prison term. But then one would have to recall that judicial review is itself an extra-textual practice.

Unwilling to eliminate the Supreme Court's function of enforcing the Constitution in this way, adherents of a philosophy of judicial restraint generally admit that in spelling out the meaning of vague constitutional phrases justices must indeed look beyond the Constitution. Their arguments then focus on how to constrain the search for external sources. Rather than simply substitute her own values and policy preferences for those of the legislature, they argue, the justice must deploy a value-neutral method of giving specific content to the Constitution's vague terms. ${ }^{20}$ Some observers have gained notoriety for the claim that a jurisprudence of original intent is such a value-neutral method. ${ }^{21}$ Originalism, however, cannot eliminate judges' need to appeal to extra-textual val-

10482 US 569 (1987).

${ }^{20}$ See, for example, Herbert Wechsler, Toward Neutral Principles of Constitutional Law, 73 Harv L Rev 1, 15-19 (1959) (principled decisionmaking requires judges to decide cases in a general and neutral way that transcends the individual case).

21 See, for example, Bork, The Tempting of America at 143-60 (cited in note 14); Edwin Meese III, Toward a Jurisprudence of Original Intention, 2 Benchmark 1 (1986); Raoul Berger, Government by Judiciary (Harvard, 1977). 
ues because any inquiry into "intent" must be indeterminate. Whose intent matters and at what level of generality? No judge can answer this question without reference to a value-laden, extratextual political theory. ${ }^{22}$

But, of course, no judge describes her own enterprise as the substitution of her value judgments for those of the legislature. Instead, lawyers and judges alike argue that the Constitution itself marks certain values as special. ${ }^{23}$ An unlikely but eloquent spokesman for this approach was Judge Bork himself, concurring in Ollman $v$ Evans. ${ }^{24}$ Over the dissent of then-Judge Scalia, in a case that expanded First Amendment protection against libel actions, Judge Bork distinguished the enterprise of "creating new constitutional rights" from that of "discern[ing] how the framers' values, defined in the context of the world they knew, apply to the world we know."2s

When a judge writes about "the central value"26 of this or that clause of the Constitution, he suggests the existence of a middle ground between the literal text of the Constitution and the subjective realm of the judge's values. One way to identify the central value or values implicit in a specific constitutional clause is to locate that clause within the overall structure of the rest of the Constitution-to ask whether the practices mandated or proscribed by the Constitution presuppose some view without which these textual requirements are incoherent. For example, the Fifth Amendment's Takings Clause seems to presuppose that property can be pre-political: if property were only the sum total of legislative entitlements, then property could never be "taken" because what the legislature declares no longer to be yours simply would not qualify as private property. Despite the devastating realist critique of the reification of property rights, ${ }^{27}$ the Constitution appears to mark as special a quasi-metaphysical view of private property.

${ }^{22}$ See Ronald Dworkin, A Matter of Principle 57 (Harvard, 1985) ("The important question for constitutional theory is not whether the intention of those who made the Constitution should count, but rather what should count as that intention.").

${ }^{23}$ This need for some source of constitutional values led many in the generation of legal scholars following Wechsler to abandon his quest for neutral principles. See, for example, John Hart Ely, The Wages of Crying Wolf: A Comment on Roe v. Wade, 82 Yale L J 920, 949 (1973) ("[a] neutral and durable principle may be a thing of beauty and a joy forever. But if it lacks connection with any value the Constitution marks as special, it is not a constitutional principle and the Court has no business imposing it.").

24 750 F2d 970 (DC Cir 1984) (en banc).

${ }^{25}$ Id at 995 (Bork concurring).

28 Id.

${ }^{27}$ For typical realist observations about the social origin and relational nature of property rights, see Morris R. Cohen, Property and Sovereignty, 13 Cornell L Q 8 (1927), and Felix S. Cohen, Transcendental Nonsense and the Functional Approach, 35 Colum L Rev 809 (1935). 
Although the constitutional text does mark some values as special, it will not settle most cases. Only a small fraction of a typical twentieth-century opinion interpreting the more familiar clauses of the Constitution focuses on the constitutional text. Instead, the elaboration of constitutional values proceeds mostly from prior decisions. By focusing on precedent-intended here to include the rationales of prior cases as well as their holdings-we do not deny that other factors play a significant role in constitutional adjudication. ${ }^{28} \mathrm{We}$ single out precedent-based arguments because such arguments generally take account of these other factors. The Court has nominally based even its boldest innovations in constitutional law upon precedent. For instance, Justice Stone argued that state-sanctioned discriminatory practices against "discrete and insular minorities" merit a diminished presumption of constitutionality not because he believed such discrimination was intrinsically evil, nor because the structure of the Constitution marks discrete and insular minorities as special. ${ }^{29} \mathrm{He}$ located this principle in prior cases. ${ }^{30}$

Why should precedent matter so much? ${ }^{31}$ The usual response-that the law values certainty-seems inadequate given the Court's willingness to depart from precedent, sometimes quite rap-

28 "[M]ost judges, lawyers, and commentators recognize the relevance of at least five kinds of constitutional argument: arguments from the plain, necessary, or historical meaning of the constitutional text; arguments about the intent of the framers; arguments of constitutional theory that reason from the hypothesized purposes that best explain either particular constitutional provisions or the constitutional text as a whole; arguments based on judicial precedent; and value arguments that assert claims about justice or social policy." Richard $\hat{H}$. Fallon, Jr., A Constructivist Coherence Theory of Constitutional Interpretation, 100 Harv L Rev 1189, 1189-90 (1987). As Fallon notes, "plausible interpretations of the cases should be considered in light of such factors as fidelity to textual language, the intent of the framers, and considerations of constitutional theory and of morality and social policy." Id at 1260. See also Philip Bobbitt, Constitutional Fate (Oxford, 1982).

${ }^{29}$ Carolene Products, 304 US at 152 n 4.

${ }^{30}$ Id, citing Pierce $v$ Society of Sisters, 268 US 510 (1925), and Meyer $v$ Nebraska, 262 US 390 (1923).

${ }^{31}$ See generally Frederick Schauer, Precedent, 39 Stan L Rev 571 (1987); Henry P. Monaghan, Our Perfect Constitution, 56 NYU L Rev 353, 387-91 (1981). For an expression of the view that stare decisis is not a rule but a principle that may be outweighed by other principles, see Ronald Dworkin, Taking Rights Seriously 38 (Harvard, 1977). Justice Powell recently noted that reliance on precedent in general, and on stare decisis in particular, is particularly important in constitutional cases because "[a]fter two centuries of vast change, the original intent of the Founders is difficult to discern or is irrelevant. Indeed, there may be no evidence of intent." Lewis F. Powell, Jr., Stare Decisis and Judicial Restraint, 47 Wash \& Lee L Rev 281, 289 (1990). 
idly, ${ }^{\mathbf{3 2}}$ when it views a particular precedent as fundamentally unsound. Moreover, concentration on precedent tends to overemphasize the role of the Supreme Court, the least politically accountable branch of government. Certainly the words and deeds of other significant constitutional actors shape our constitutional understanding. ${ }^{33}$

Perhaps the best answer is an institutional one: the Supreme Court is most qualified to read cases, especially its own cases. Rightly or wrongly, the battle for constitutional meaning occurs primarily in the interpretation of prior cases. And competing characterizations of the level of generality at which to describe rights often constitute the principal weapons in that battle.

\section{The Problem of Abstraction}

Bowers $v$ Hardwick ${ }^{34}$ illustrates the centrality of the levels of generality question. Writing for the majority, Justice White contended that "[t]he issue presented is whether the Federal Constitution confers a fundamental right upon homosexuals to engage in sodomy."3s In dissent, Justice Blackmun argued that the case was

no more about "a fundamental right to engage in homosexual sodomy" . . . than Stanley v Georgia, 394 US 557 (1969), was about a fundamental right to watch obscene movies, or Katz $v$ United States, 389 US 347 (1967), was about a fundamental right to place interstate bets from a telephone booth. Rather, this case is about "the most comprehensive of rights and the right most valued by civilized men," namely, "the right to be let alone."38

Justice Blackmun may have overstated the point, since Katz

${ }^{32}$ Compare West Virginia State Board of Educ. v Barnette, 319 US 624 (1943) (compulsory flag salute held to violate First and Fourteenth Amendments), with Minersville School Dist. v Gobitis, 310 US 586 (1940) (compulsory flag salute held not to violate Fourteenth Amendment).

${ }^{33}$ See Robert F. Nagel, Constitutional Cultures: The Mentality and Consequences of Judicial Review (California, 1989) (courts, acting as super-bureaucracy, have transformed Constitution into ever-changing political agenda); Bruce A. Ackerman, The Storrs Lectures: Discovering the Constitution, 93 Yale L J 1013, 1056 (1984) (claiming Lochner had the potency of a formal constitutional amendment); Bruce A. Ackerman, Reconstructing American Law (Harvard, 1984) (interpreting the New Deal as an unofficial structural amendment to the Constitution).

${ }^{34} 478$ US 186 (1986). Professor Tribe argued the case for Hardwick before the Supreme Court.

${ }^{36}$ Id at 190.

${ }^{36}$ Id at 199 (Blackmun dissenting) (citing Olmstead v United States, 277 US 438, 478 (1928) (Brandeis dissenting)). 
involved a type of "privacy" that "does make the claimant's substantive conduct irrelevant; at issue [in a case like Katz] is the government's manner of discovering the conduct." ${ }^{37}$ But he overstated it only a little, ${ }^{38}$ because the Court need not have regarded Hardwick as a case about "homosexual sodomy" at all. The state statute at issue drew no distinction between homosexual and heterosexual intimacies.

The majority and the dissenters in Hardwick argue over how abstractly to describe the right at issue. The majority describes the right narrowly, the dissent broadly. These alternative descriptions evidently reflect the fact that the majority and dissent have reached different conclusions as to whether Hardwick's behavior is constitutionally protected. As such, we might view them as shorthand for the holding and the dissent. Yet the characterizations are the starting points for the analysis. Because the majority and dissent ask different questions, it is not surprising that they give different answers.

The majority's question answers itself. Describing a claimed right in very specific terms-here, as a "right to engage in homosexual sodomy"-disconnects it from previously established rights. To the majority, the cases on which Michael Hardwick relied were inapposite because they did not deal with the specific right the majority stated he was claiming. The majority pigeonholed the earlier cases to ensure that no right to privacy broad enough to encompass Hardwick's behavior would emerge. ${ }^{39}$ Pierce $v$ Society of Sisters ${ }^{40}$ and Meyer $v$ Nebraska"1 dealt "with child rearing and education";42 Prince v Massachusetts, ${ }^{43}$ "with family relationships"; 44 Skinner v Oklahoma, ${ }^{45}$ "with procreation"; ${ }^{46}$ Loving $v$ Virginia, ${ }^{47}$

\footnotetext{
37 Jed Rubenfeld, The Right of Privacy, 102 Harv L Rev 737, 749 (1989).

${ }^{38}$ It overstates matters to say, as Rubenfeld did, that Justice Blackmun's "statement . . was plainly wrong." Id.

39 Thomas B. Stoddard, Bowers v. Hardwick: Precedent by Personal Predilection, $54 \mathrm{U}$ Chi L Rev 648, 653 (1987) ("By sorting out cases according to labels adopted in previous decisions, the majority acted in a manner more befitting mail clerks than justices of the Supreme Court. ... [The majority opinion] is, unfortunately, little more than judgment by pigeonhole.").

40268 US 510 (1925).

4262 US 390 (1923).

12 Hardwick, 478 US at 190.

43 321 US 158 (1944).

" Hardwick, 478 US at 190.

43316 US 535 (1942).

4 Hardwick, 478 US at 190.

${ }^{47} 388$ US I (1967).
} 
"with marriage"; 48 Griswold $v$ Connecticut" and Eisenstadt $v$ Baird, "with contraception",;1 and Roe v Wade," "with abortion." ing these last three cases: "a fundamental individual right to decide whether or not to beget or bear a child." protect homosexual sodomy.

The dissent begins with an equally conclusory formulation of the issue. If the fundamental right protected as "liberty" and established in prior cases is indeed "the right to be let alone," as the dissent at first suggests, then of course the Georgia statute is unconstitutional, or at least triggers strict scrutiny, since far from leaving people like Hardwick alone, it brands them as criminals. But a right to be let alone cannot serve as a constitutional rule of decision. A right to be let alone while doing what? While harming others? Harming others in what way? As determined by whom? These questions make clear the need for a less abstract formulation of the right at stake, and indeed the dissent provided one. The dissent would have recognized "the fundamental interest all individuals have in controlling the nature of their intimate associations with others." $" s 5$

Thus, although both the Hardwick majority and dissent began from question-begging formulations of the issue at stake, each arrived at a characterization of the prior cases that is at least arguably reasonable. But their characterizations produced strikingly different results. The "right" to make decisions about family, marriage, or procreation did not protect Hardwick's conduct. The "right" to control the nature of one's intimate associations did protect it.

Before addressing the merits of these competing abstractions, we consider an important caveat that must accompany any discussion of levels of generality. Although we have described the enterprise of designating fundamental rights as a question of how abstractly to portray rights, we do not posit a single dimension along which abstraction must be measured. A right may be broad along one dimension, while narrow along another. For example, as ap-

\footnotetext{
48 Hardwick, 478 US at 190.

4831 US 479 (1965).

so 405 US 438 (1972).

s1 Hardwick, 478 US at 190.

${ }^{52} 410$ US 113 (1973).

${ }^{53}$ Hardwick, 478 US at 190.

st Id.

${ }^{85}$ Id at 206 (Blackmun dissenting).
} 
plied to the facts in Hardwick, the right identified in the prior cases by the dissent is broader than the right identified by the majority. Unlike the right to decide whether to beget a child, the right to control intimate associations presumably includes a right to control intimate sexual associations with members of the same sex.

However, there are cases where the majority's right would be broader. Consider, for example, a woman's asserted right to utilize a sperm bank or to make a surrogate motherhood contract. Under the majority's formulation, these rights are fundamental: the decision to undergo anonymous artificial insemination is a decision to bear a child, and the decision to supply an ovum for laboratory fertilization and subsequent incubation by a "surrogate mother" is a decision to reproduce without incurring the burdens of pregnancy. But the fundamental liberty protected by the Hardwick dissent would not protect the right to use a sperm bank or the right to use a surrogate. The exercise of such rights would reflect decisions to beget a child without any intimate association.

How should we choose between competing abstractions? We may gain some insight into this problem by considering a related puzzle: what is the connection among the rights protected within the Bill of Rights? Justice Harlan suggested one answer in his dissent in Poe $v$ Ullman. ${ }^{56}$ The liberty protected by the Due Process Clause of the Fourteenth Amendment

is not a series of isolated points pricked out in terms of the taking of property; the freedom of speech, press, and religion; the right to keep and bear arms; the freedom from unreasonable searches and seizures; and so on. It is a rational continuum which, broadly speaking, includes a freedom from all substantial arbitrary impositions and purposeless restraints . . . and which also recognizes, what a reasonable and sensitive judgment must, that certain interests require particularly careful scrutiny of the state needs asserted to justify their abridgment. ${ }^{\text {sz }}$

Justice Harlan was engaged in a process of interpolation and extrapolation. From a set of specific liberties that the Bill of Rights explicitly protects, he inferred unifying principles at a higher level of abstraction, focusing at times upon rights instrumentally required if one is to enjoy those specified, and at times upon rights logically presupposed if those specified are to make sense. Al-

${ }^{86} 367$ US 497 (1961).

${ }^{87}$ Id at 543 (Harlan dissenting) (citations omitted). 
though the immediate concern in Poe was a criminal ban on the use of contraception, Justice Harlan's method applies broadly. Suppose that the government conspired with the TV networks to include subliminal messages urging viewers to "return the Administration to office" in key broadcasts shortly before a national election. Would this action violate any of your rights? The literal terms of the First Amendment do not prohibit such messages, but Justice Harlan's point was that the freedom of speech, the freedom of religion, and so forth make sense only if connected by a broader and underlying principle of freedom of thought and conscience. Applying his method to the hypothetical subliminal messages, we might say that they violate the First Amendment, even though we cannot pinpoint the precise provision violated.

Moreover, by proposing that we perceive rights on a "rational" continuum, Justice Harlan indicated that rights make more sense if abstracted from the particular spheres of life they protect. Free speech is an empty freedom if not possessed by a free mind.

Justice Harlan's Poe dissent applies no less to the enterprise of connecting cases than it does to that of connecting clauses of the Constitution. If constitutional decisionmaking is to be "rational," one must seek unifying principles to link disparate decisions. To the extent that it coheres with our experience to view decisions about childrearing and family, decisions about marriage, and decisions about procreation as concerning completely isolated areas of life-as did the Hardwick majority-we will not seek an underlying unifying principle. Perhaps the Hardwick majority did have a unifying principle in mind: protection of the traditional nuclear family. But this principle explains too little, for the Constitution guarantees reproductive freedom to single mothers no less than to married ones, and the right to familial association extends beyond the traditional nuclear family. ${ }^{58}$ Nor could one plausibly connect a line drawn around the nuclear family with constitutional text, structure or history.

However, if presumptively excluding government from such areas of life as marriage, procreation and child-rearing nevertheless appears to be a connected project-if the freedoms at issue involve different manifestations of the same underlying liberty to control the nature of one's intimate associations-then we might well con-

\footnotetext{
ss See Eisenstadt, 405 US at 447 (dissimilar availability of contraceptives for married and single women violates Fourteenth Amendment); Moore, 431 US 494 (city zoning interests subordinate to societal function of extended family).
} 
nect the "points" of liberty in the way the Hardwick dissenters did. ${ }^{\text {so }}$

The Supreme Court has not always recognized the relationship between liberties, even those which seem quite closely linked. Consider, for example, one area of the law that has been characterized by quite artificial boundaries: the scope of First Amendment protection afforded to various media. In Kovacs $v$ Cooper, ${ }^{60}$ the Court upheld a city ordinance banning the use of sound trucks on the public streets as a valid time, place, and manner restriction. More remarkable than the result, however, is a statement in Justice Jackson's concurrence. Emphasizing the narrowness of the holding, he distinguished sound trucks from movies, radio, and other media. "Each" medium, Justice Jackson claimed, "is a law unto itself, and all we are dealing with now is the sound truck." ${ }^{11}$ Justice White expressed a similar sentiment over thirty years later in Metromedia, Inc. $v$ San Diego, ${ }^{62}$ which involved a challenge to San Diego's billboard ordinance. After perfunctorily acknowledging that the First Amendment contains broad principles, he defined his task narrowly: "[w]e deal here with the law of billboards."

The claim that a unique body of law applies to each medium of expression is descriptively and normatively false. Were there really a unique law of billboards, distinct from the law of soundtrucks and other media, there would be no reason for the authors of the Kovacs and Metromedia opinions to have considered cases dealing with other media, and to their credit, they did at least cite some such cases. Moreover, rationality dictates that one not segregate the reasoning applicable to one medium from the reasoning that has prevailed with respect to other media. How would the segregated approach cope with a new medium? Must there be a unique "law of compact discs" distinct from the prior "law of phonograph records?" For that matter, how abstractly are we to define a medium? Is there a "law of Betamax VCRs" distinct from "VHS VCRs?" From what sources does one infer the "law of fax machines?" If judges can consult neither general principles of First Amendment law nor prior historical traditions-by definition a new medium arrives on the scene without historical tradi-

\footnotetext{
69 Justice Harlan himself did not believe that the right of gay intimacy lies on the same rational continuum as the right of married couples to use contraception. Poe, 367 US at 553 (Harlan dissenting). However, that does not preclude us from faithfully applying his method to reach a different conclusion.

Bo 336 US 77 (1949).

61 Id at 97 (Jackson concurring).

62 453 US 490 (1981).

${ }^{63}$ Id at 501 (plurality opinion).
} 
tions-they will be completely at sea. In this way, the capacity to generalize serves not as a source of judicial subjectivity, but as a limit upon it.

In opposition to the radical reductionism exemplified by the reasoning of opinions like Hardwick and Metromedia, Justice Harlan's suggestion in Poe challenges us with an admittedly imprecise and indeterminate mission: to seek unifying principles that will push constitutional law toward rationality.

Nonetheless, more than one unifying principle is almost always available. Thus, according to Paul Brest, "[t]he indeterminacy and manipulability of levels of generality" 64 require the Court to make value choices in deciding whether to infer a fundamental right from a constellation of precedent and historical practice.

Among Brest's authorities for this proposition is, somewhat surprisingly, Robert Bork. ${ }^{65}$ Brest adds however, that the indeterminacy of abstraction plagues Bork's originalism too. If the Court must not refer to the Framers' most specific intent-as Bork claims it must not in order to save Brown $v$ Board of Education ${ }^{66}$ from destruction by the specific views about segregation held by the authors of the Fourteenth Amendment-how can it select a meaning for equality in a value-neutral way? ${ }^{67}$

Bork misapprehends this criticism. In response to Brest, he argues that "[o]riginal understanding avoids the problem of the level of generality in equal protection analysis by finding the level of generality that interpretation of the words, structure, and history of the Constitution fairly supports." 68 This isn't a solution. This is the problem restated. As we show in the next section, the interpretation of words usually can "fairly support" a wide variety of conclusions.

\footnotetext{
64 Paul Brest, The Fundamental Rights Controversy: The Essential Contradictions of Normative Constitutional Scholarship, 90 Yale L J 1063, 1085 (1981). See also Tribe, American Constitutional Law $\$ 15-21$ at 1427-28 (cited in note 12).

${ }^{65}$ Brest, 90 Yale L J at 1084 (cited in note 64).

os 347 US 483 (1954).

${ }^{87}$ See Brest, 90 Yale L J at 1090-92 (cited in note 64). See also Gene R. Nichol, Jr., Bork's Dilemma (Book Review), 76 Va L Rev 337, 344-46 (1990) (Bork manipulates the level of generality at which he discusses the intent of the Framers so as to preserve politically popular decisions like Brown); Bruce A. Ackerman, Robert Bork's Grand Inquisition (Book Review), 99 Yale L J 1419, 1422-25 (1990) (Bork gives no indication that he has conducted the kind of historical research necessary to support his conclusions about what the Framers and ratifiers intended).
}

${ }^{68}$ Bork, The Tempting of America at 150 (cited in note 14). 


\section{How LAW Is Like Literature ${ }^{69}$}

How should a judge faced with a case of first impression apply prior decisions in cases involving related but different facts? Ronald Dworkin analogizes the process of using precedent to the composition of a chain novel, a book written by many authors. Each successive author must continue the story written by those who preceded her. In Dworkin's analogy, just as we measure the quality of a chain novelist's creation by how well it builds upon what came before, so too the judge's opinion is evaluated by asking how well it fits with precedent.

Dworkin admits the analogy is imperfect. For instance, judges sometimes overrule cases, or confine them to their facts. But we shall assume the analogy is sufficiently close that we may obtain useful insights about law by examining literature. ${ }^{70}$

The most important insight is that more than one ending can be consistent with the story that came before. Consider Great Expectations. In Dickens' original manuscript Pip's love for Estella remains forever unrequited. However, on the advice of Edward Bulwer Lytton, Dickens changed the ending, uniting the hero and his love. He then published the sanguine version. ${ }^{71}$ Which ending fits the story better? Bulwer Lytton-in a position like a chain novelist--judged that Victorian audiences would prefer the happy ending. Later critics have tended to prefer Dickens' original ending, because their sensibilities were less sentimental than the Victorians'. George Bernard Shaw, who edited the novel for a 1937 publication, used the original ending, relegating the other to a postscript for "[s]entimental readers who still like all their stories to end at the altar rails."

What causes one reader to prefer one ending and a different reader to prefer a different ending is not consistency in the $a b$ stract, but aesthetic value judgments of one sort or another. These value judgments are necessarily external to the text. It is worth

69 This section is titled after an essay by Ronald Dworkin called "How Law is Like Literature," in Dworkin, A Matter of Principle at 146-66 (cited in note 22).

${ }^{70}$ The question of how closely legal interpretation should resemble literary interpretation, though quite controversial (compare James Boyd White, What Can a Lawyer Learn from Literature? (Book Review), 102 Harv L Rev 2014 (1989), with Richard A. Posner, Law and Literature: A Misunderstood Relation (Harvard, 1988)), is beyond the scope of this article. See generally Robin West, Law, Literature, and the Celebration of Authority (Book Review Exchange), 83 Nw U L Rev 977 (1989).

71 Anny Sadrin, ed, Great Expectations 10 (Unwin Hyman, 1988).

${ }^{22}$ George Bernard Shaw, ed, Great Expectations xxiii-xxvi (R \& R Clark, 1937) (quoted in Sadrin, ed, Great Expectations at 179 (cited in note 71)). 
pausing over the question of what it means to say that a value is external to a text. In one sense, all meaning is external to text: to attribute meaning to a collection of ink marks on paper or vibrations of the air presupposes that the reader or listener can decipher the linguistic code being used. Great Expectations is meaningless to someone who does not understand English, the rules of which are certainly external to the novel itself.

This problem is not solved by assuming that we may implicitly append to any text a guide to the language in which it is written. Because such a guide must itself be decoded, there will remain an irreducible minimum of meaning that the reader will have to supply on her own. ${ }^{73}$ People bother to write novels, or to speak to one another, because they accept that they are each supplying the same irreducible meaning. When two people look at the same object and call it an elephant we have no way of knowing that their respective subjective experiences are even remotely similar. Yet our belief that we can and do communicate to one another indicates that we assume there is a common human experience of the world.

Without similar unspoken extra-textual assumptions, it makes no sense to speak of the Constitution as having a meaning. Since the Constitution is itself a text, all of the assumptions necessary to make sense of any text naturally apply to the Constitution. The question here is whether there must be additional unspoken assumptions. Consider the widely shared belief that the Constitution is the supreme law of the land. This cannot be true merely because the Supremacy Clause of Article VI says it is. Suppose some law professors, dissatisfied with the familiar Constitution, write their own constitution and include a clause declaring it the supreme law of the land. What makes the former the actual supreme law of the land and the law professors' effort a mere conceit are certain propositions about political theory and history. The Supremacy Clause binds us to the extent that readers of the Constitution agree that sovereignty derives from the people, that one generation may bind another, and that the Philadelphia Convention of 1787 and subsequent ratification processes expressed the national will to create a lasting government.

The unspoken assumptions that give meaning to the constitutional text are more controversial than those that give meaning to language in general. Although we cannot logically refute the solip-

\footnotetext{
${ }^{73}$ See generally Ludwig Wittgenstein (G.E.M. Anscombe, trans), Philosophical Investigations (Oxford, 3d ed 1958).
} 
sist, few of us seriously doubt that there is an external world about which we can actually exchange information. By contrast, many question the assumptions underlying the legitimacy of the Constitution. Some deny that democracy, which can degenerate into mob rule, is preferable to enlightened despotism. Others wonder why the views of long-dead generations should shape our government. Still others challenge the premise that we should be bound by an instrument created without consulting women, slaves, or those without property-the majority of the adult population. ${ }^{74}$ Why should we accept such premises?

Perhaps these are not legal questions at all. Positive law arguably proceeds from the axiom that we all agree that this or that book contains the law to be interpreted. According to this view, deciding between the Constitution of 1787 or the 1990 "constitution" of the law professors is a matter for political theorists, not the law. The difficulty with this explanation is that we must apply extra-constitutional values not just to determine what the Constitution is, but to determine what the Constitution means. This last question, at least, is a matter for law.

The need to resort to extra-constitutional values in interpreting the Constitution manifests itself in the area of fundamental rights. For example, in Roe $v$ Wade the Court determined whether and under what circumstances a woman's decision to have an abortion is part of the fundamental right to privacy recognized in the contraception cases..$^{75}$ Viewed as literature, we can easily reconcile the majority opinion in Roe with prior cases. If Griswold and Eisenstadt tell a story of freedom to avoid motherhood before conception, Roe continues the story so as to protect that right for a time after conception.

But can we say that Griswold and Eisenstadt dictated the result in Roe? Certainly the dissenting view in Roe is not necessarily inconsistent with the contraception decisions on their own terms. ${ }^{76}$

\footnotetext{
${ }^{74}$ See, for example, Thurgood Marshall, Reflections on the Bicentennial of the United States Constitution, 101 Harv L Rev 1, 5 (1987) (" 'We the People' no longer enslave, but the credit does not belong to the framers. It belongs to those who refused to acquiesce in outdated notions of 'liberty,' 'justice,' and 'equality,' and who strived to better them."); William Kunstler, Keynote Address, Symposium on Federal and State Methods of Repressing Political Activism, 15 NYU Rev L \& Soc Change 429, 430 (1987) (original Constitution "was framed by Gents; it was filled with compromises that were palatable to some of the Gents, such as making Blacks $3 / 5$ of Whites and so on. ...").

${ }^{78}$ See Eisenstadt, 405 US 438; Griswold, 381 US 479.

${ }^{78}$ Whether the dissenting opinions comport with the prior cases is a different matter. Justice White concurred in the judgment in Griswold because the Connecticut statute there regulated what he deemed a fundamental liberty interest in the marriage relationship. 381
} 
According to the story told by the dissenters, conception marks the start of a new chapter. In this story, state legislators are free to restrict abortions so long as the restrictions meet the minimal requirement of rationality.

To say that the majority and the dissent each tell consistent stories is not to say that there is no principled reason to prefer one story over the other. Each side will appeal to what it perceives to be widely shared values. Those who would deny that a right is fundamental will often march under the banner of majoritarianism. Who are unelected judges to declare $\mathrm{X}$ a fundamental right, they will ask, when so many states do not consider it so? The other side will point to all of the rights deemed fundamental in the past despite state efforts to abridge them and will locate $\mathrm{X}$ within the scope of the previously described rights. And both sides will make claims about the kind of society that protects or abridges right X. ${ }^{77}$ Just as in literature the criteria for judging which ending to a story is preferable are external to the story itself, the criteria for judging the level of generality of a fundamental right must come from outside the four corners of the prior opinions. In literature, the external criteria are aesthetic. In law, they are political and moral, and, to the extent that lawyers are trained in a particular method of reasoning-and to the extent the word "legal" describes the praxis of lawyers-they are also legal.

Thus far we have contended that until any given point a work of literature will be consistent with more than one ending. But it will not be equally consistent with all endings. Though the internal structure of a text may be consistent with ending A or ending B, some endings are surely beyond the pale. Or are they?

Suppose we rewrite the final chapter of Great Expectations as a non sequitur. Space aliens eat Pip and Estella. Or Miss Haversham is reincarnated as a giant talking cockroach, while Pip emigrates to Bolivia to become a shepherd. Or why not a final chapter totally unconnected with what precedes it? Replace the original ending with this essay, perhaps translated into Swedish, and delete the references to Great Expectations. The prior text does not logically rule out even these bizarre examples. Just as the choice be-

US at 502-03. Yet his Roe dissent rested largely on principles of judicial restraint in the face of majority sentiment, 410 US at 221-23, principles equally applicable in Griswold.

7 Compare Moore, 431 US at 503-04 (plurality opinion) (extolling the family as an institution through which "we inculcate and pass down many of our most cherished values, moral and cultural"), with Hardwick, 478 US at 197 (Burger concurring) (warning that to "hold that the act of homosexual sodomy is somehow protected as a fundamental right would be to cast aside millennia of moral teaching"). 
tween the original ending and the editor's amendment came down to aesthetic criteria, so too does the decision to reject these bizarre endings.

The difference is that the aesthetic convictions that rule out the non sequitur endings are widely shared. Most readers will prefer books written in only one language.$^{78}$ By contrast, more readers will disagree over whether tragic endings are more desirable than happy ones. The difference, however, is a matter of degree rather than kind. It is also culturally contingent: we can imagine an angst-ridden polyglot nation in which all agree that tragedy is superior to comedy, though the people are deeply divided as to the ideal number of languages in which a book should be written.

In law too, widely shared beliefs about what makes sense will rule out some results. Suppose that Griswold had come out the other way-that the Court held that there is no fundamental right of married couples to use contraception. This would seemingly preclude Roe. After all, it would make no sense to uphold a fundamental right to abort a fetus, but not a right to prevent conception. Anti-Roe seems to follow a fortiori from anti-Griswold.

But even this judgment is not a matter of pure logic. Concurring in Thornburgh $v$ American College of Obstetricians \& Gynecologists, ${ }^{79}$ Justice Stevens argued that, as between the decision whether to use contraception and the decision whether to have an abortion, "it is the post-conception decision that is more serious," and therefore implicates an arguably greater liberty interest. The decision not to use contraception is a decision to risk becoming a mother, whereas the decision not to have an abortion is a decision actually to become a mother, and therefore to accept the joys and burdens of motherhood. Although Justice Stevens conceded that in the abortion context there may be a stronger countervailing interest to be weighed against the woman's reproductive freedom, his analysis suggests a not wholly implausible means of reconciling Roe with anti-Griswold.

Moreover, many other rules of constitutional decisionmaking might explain the judgment that there is a fundamental right to an abortion but not to contraception. Perhaps the justices secretly adhere to a canon of constitutional construction requiring that fundamental rights begin in vowels: abortion is in, contraception out. No one would actually argue for such a rule, but this fact is socially and culturally contingent. There would be widespread agreement

\footnotetext{
${ }^{78}$ But see James Joyce, Finnegan's Wake (Viking, 1939).

79 476 US 747,776 (1986) (Stevens concurring).
} 
that such a rule of law is arbitrary because it relies on irrelevant information. Yet the criteria of relevance are themselves culturally shaped. In colonial Salem, for instance, a defendant could be convicted of witchery because an examination of her body revealed unusual growths, regarded as indicia of her pact with the devil.. ${ }^{80}$ No doubt this procedure seems arbitrary and cruel to us, but it was deemed to provide highly credible evidence in that place and time.

The comparison with literature shows that the internal structure of prior cases combined with an appeal to widely shared values can rule out some formulations of a fundamental right. The difficulty arises when litigants appeal to values that are not shared. And in any interesting case, such conflicting appeals will be available.

\section{How Law is UnLike Mathematics}

One might rebut the analysis of the previous section by focusing on yet another important way in which law is not like literature. Except in some self-conscious modern works, ${ }^{81}$ the author of a piece of literature does not usually attempt to justify her enterprise within the enterprise itself. But that is precisely what judicial opinions do. Within an opinion the judge argues why the opinion fits the prior cases. The literary analogy does not capture this argumentative element of law. Might the self-referential quality of legal interpretation render law free from the indeterminacy that plagues literary interpretation? To answer this question we compare the judicial enterprise with another self-justificatory process, mathematical proof. However, we will show that this comparison only reinforces the conclusion that specifying an appropriate $a b$ straction to characterize prior cases requires value choices.

What is the nature of mathematical proof? Imre Lakatos challenged the conventional view of mathematics as the accumulation of proven truths. ${ }^{82}$ Instead, Lakatos claimed, mathematics is a process by which proofs become more rigorous as mathematicians subject them to counterexamples and criticisms. Lakatos' insights have numerous applications in the law, ${ }^{83}$ one of which bears upon

so Richard Weisman, Witchcraft, Magic, and Religion in 17th-Century Massachusetts 15 \& $n 48$ (Massachusetts, 1984).

si See, for example, Philip Roth, The Facts: A Novelist's Autobiography (Farrar, Straus \& Giroux, 1988) (in which the fictional protagonist of several of Roth's prior works criticizes Roth's autobiography).

"Imre Lakatos, Proofs and Refutations: The Logic of Mathematical Discovery (Cambridge, 1976).

s3 Compare Robert M. Fisher, The Logic of Economic Discovery (NYU, 1986) (applying Lakatos' insights to economics). 
the abstraction problem. For that reason, we shall briefly describe Lakatos' analysis of mathematical proof.

\section{A. Mathematical Enterprise According to Lakatos}

Consider the following proof.

Proposition: the sum of the angles of any triangle is $180^{\circ} .{ }^{84}$

Proof:

1. Let $a, b$, and $c$ be the angles of triangle $A B C$.

2. Adjacent to $A B C$ draw similar triangle $A^{\prime} B^{\prime} C^{\prime}$. Since the triangles are similar, the angle opposite $A^{\prime}$ will equal angle a, as shown in figure 1.

3. Let $d$ be the angle between segments $A$ and $C$. Since $c, d$, and $a$ (of $A^{\prime} B^{\prime} C^{\prime}$ ) form a straight angle, we have $a+d+c=$ $180^{\circ}$.

4. But A is a transversal that cuts parallel segments $\mathrm{C}$ and $\mathrm{C}$. By Euclid's Fifth Postulate, when two parallel lines are cut by a transversal, alternate interior angles are equal. Thus, $b=d$.

5. Substituting this into our previous equality, $a+b+c=$ $180^{\circ}$, and we have completed the proof.

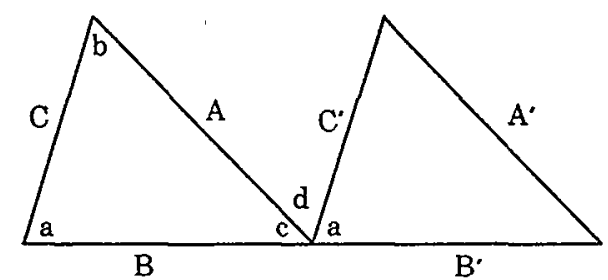

Figure 1

\footnotetext{
${ }^{84}$ Lakatos illustrated his method by a dialogue concerning proof of a theorem about regular polyhedra, namely that for all regular polyhedra, $\mathrm{V}-\mathrm{E}+\mathrm{F}=2$, where $\mathrm{V}=$ the number of vertices, $\mathrm{E}=$ the number of edges, and $\mathrm{F}=$ the number of faces. Limitations of space, and the recognition that readers of this article may find the excursion into solid geometry daunting, have led us to substitute a somewhat simpler, and hopefully more familiar example. For the limited purposes of this article, no loss of generality results.
} 


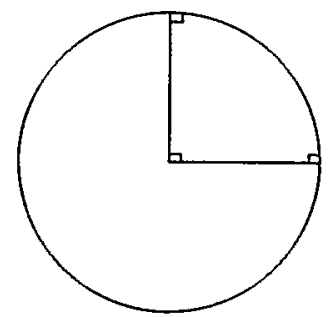

Figure 2

(View from the north pole)

Now suppose that someone comes along claiming to have discovered a triangle for which the sum of the angles is greater than $180^{\circ}$. Her triangle is drawn on the surface of a sphere. It has one vertex at the north pole, and the other two on the equator, as shown in figure 2. Each of the angles formed by the intersection of the equator with the other legs is a right angle, so their sum is $180^{\circ}$. Adding the angle at the north pole, we have a sum greater than $180^{\circ}$.

What are we to do with the object of figure 2? Lakatos identifies three approaches that mathematicians typically take when confronted with counter-examples: (1) monster-barring; ${ }^{85}$ (2) exception-barring, ${ }^{86}$ and (3) lemma-incorporation. ${ }^{87}$

Monster-barring, as the name suggests, treats the object of figure 2 as no counter-example at all. "That is not a triangle at all," says the monster-barrer. "The word triangle does not include enclosed areas on the surface of a sphere. Therefore, you haven't provided a counter-example, but a monster. My proof is still valid." The monster-barrer preserves the truth of his theorem by brute force, defining away all challenges.

Exception-barring is a more sophisticated approach. The exception-barrer admits that there can be a triangle on the surface of a sphere, and therefore that figure 2 is indeed a counter-example. Knowing, however, that the proposition still holds true for a great many triangles, the exception-barrer refuses to sacrifice it. Consequently, she modifies her proposition to state:

Exception-Barrer's Modified Proposition: For all triangles that are not on the surface of a sphere, the sum of the angles = $180^{\circ}$.

\footnotetext{
${ }^{8 s}$ Lakatos, Proofs and Refutations at 14 (cited in note 82).

${ }^{86}$ Id at 24.

${ }^{87}$ Id at 33 .
} 
The difficulty with the modified proposition is that we no longer have any confidence in our proof. Because the exceptionbarrer has modified the proposition in a completely ad hoc manner, she does not confront whatever was wrong with our proof in the first place. Ergo, she cannot guarantee that no more exceptions lurk about.

What is needed, according to Lakatos, is a method that relates the exception to the proof. That method is lemma-incorporation. Because the existence of a counterexample to the proposition means that some step ("lemma") of the proof must be false, the lemma-incorporator searches for the false lemma. In our example, we would find that step 4, which assumed the truth of Euclid's Fifth Postulate, is the suspect step. The Fifth Postulate holds for Euclidean surfaces, ${ }^{88}$ but not for all surfaces, and not for the surface of a sphere. ${ }^{89}$ The lemma-incorporator now modifies the proposition to state:

Lemma-Incorporator's Modified Proposition: For all triangles on surfaces where Euclid's Fifth Postulate holds, the sum of the angles $=180^{\circ}$.

Lemma-incorporation is superior to exception-barring because the former preserves the original proof. We may now deploy step 4 of our original proof with confidence, because we have made its controversial assertion into an explicit assumption. The original proof is valid, but for a limited domain. By lemma-incorporation we have specified that domain of validity.

\section{B. Lakatos and the Law}

We begin our application of Lakatos by examining monsterbarring in the legal world. A mathematical monster-barrer, when faced with a triangle on the surface of a sphere, blithely asserts: "that's not a triangle at all, so my theorem is still true." $\mathrm{He}$ attempts to make the counter-example go away by brute force. In legal terms, he draws a distinction without a difference.

Consider the Supreme Court's effort to delineate when the case or controversy requirement of Article III allows standing to a citizen who claims to be injured in her capacity as a taxpayer. In holds.

${ }^{88}$ Indeed, a Euclidean surface is often defined as one in which the Fifth Postulate

${ }^{89}$ On the surface of a sphere, "parallel lines" are great circles that intersect at exactly two points. The mathematically minded reader may wish to verify for herself that the Fifth Postulate does not hold. (Hint: consider a transversal that cuts two great circles near one of their points of intersection.) 
Flast $v$ Cohen, ${ }^{90}$ a taxpayer brought suit challenging the expenditure of federal funds to subsidize religious education. The Court held taxpayer standing permissible. But fearing a rash of taxpayer suits, the Court limited the principle to cases where the taxpayer "allege[s] the unconstitutionality only of exercises of congressional power under the taxing and spending clause of Art. I, $\S 8$, of the Constitution." ${ }^{\prime 91}$ Sure enough, fourteen years later the Court denied standing in Valley Forge Christian College $v$ Americans United for Separation of Church and State, Inc. ${ }^{92}$ because the challenged action in that case "was not an exercise of authority conferred by the taxing and spending clause of Art. I, $\S 8$ [but] an evident exercise of Congress' power under the Property Clause, Art. IV, § 3, cl. 2." There may be good reasons to deny taxpayer standing in some cases and allow it in others, but it is difficult to comprehend why the denial should turn on the clause of the Constitution pursuant to which Congress exercises power. This is true first because a taxpayer may suffer more via the unconstitutional disposition of property (as in Valley Forge) than via a budgetary expenditure, and second because more than one clause of the Constitution typically authorizes a given act of Congress.

The taxpayer standing cases exemplify legal monster-barring. They cordon off whole areas of law by judicial fiat. Just as the mathematical monster-barrer defines away the non-Euclidean triangle, so the judicial monster-barrer arbitrarily limits the scope of his rule.

Returning to the fundamental rights context, we might ask if Roe follows logically from Griswold and Eisenstadt. A monsterbarrer who wished to retain Griswold and Eisenstadt while jettisoning Roe might argue as follows: because the contraception cases dealt with the liberty to decide whether or not to have sex without children before conception, abortion does not even implicate the liberty these cases deem fundamental..$^{94} \mathrm{~A}$ monster-barrer asserts that his level of generality is appropriate, without arguing why it should not be otherwise. Monster-barring is no more intellectually satisfying in law than in mathematics.

392 US 83 (1968).

91 Id at 102.

92454 US 464 (1982).

2s Id at 480 (footnote omitted).

94 Perhaps Lakatos unwittingly anticipated the application of his model to the abortion question. Early in Lakatos' dialogue, the monster-barring student asserts that a "woman with a child in her womb is not a counterexample to the thesis that human beings have one head." Lakatos, Proofs and Refutations at 15 (cited in note 82). 
Turning to the next approach to proof, it is easy to see the legal analogue to exception-barring. Recall that the mathematical exception-barrer adjusts her proposition without examining the associated proof. Compare those instances when the Court relies on the holdings of prior cases while ignoring their rationales. An example is Morrison $v$ Olson ${ }^{95}$ Although the crucial separation of powers inquiry identified by the Court in its prior cases clearly focused on the nature of the powers given to an official removable by the Executive, ${ }^{96}$ Morrison overcame these distinctions by substituting a balancing test: "the real question is whether the removal restrictions [on the office of the independent counsel] are of such a nature that they impede the President's ability to perform his constitutional duty. ..."97 The Court found, not surprisingly, that its balancing test produced the same results in the prior cases as had their actual rationales and then proceeded to apply the test to the case before it.

Although legal exception-barring produces results consistent with precedent, it does so by undermining those very precedents. Presumably, one reason for relying on previous decisions is the belief that they rest upon sound reasoning. ${ }^{98}$ When the Court disavows or ignores that reasoning, it weakens the precedents upon which it relies.

A particularly egregious example of exception-barring can be seen in the Supreme Court's recent decision in Employment Division $v$ Smith ${ }^{99}$ In Smith, two Native Americans who had been denied state unemployment benefits because they were dismissed from their jobs for using peyote, an illegal drug, claimed that since their religion required them to use peyote for ritual purposes, the denial of benefits violated their First Amendment right to free exercise of religion. The Court held that there was no constitutional denial. En route to reaching this conclusion, the Court did not ask whether the state's interest in criminalizing peyote was sufficiently compelling to justify the burden upon the Native Americans' reli-

9s 487 US 654 (1988).

${ }^{96}$ Compare Myers v United States, 272 US 52 (1926) (President must have power to remove executive officials), with Humphrey's Executor v United States, 295 US 602, 629 (1935) (allowing limitations on President's power to remove "quasi-legislative and quasijudicial" officials).

${ }^{87} 487$ US at 691.

${ }^{83}$ The doctrine of stare decisis also rests upon the need for certainty in the law, but this has less to do with reasoning from precedent in new settings than with following precedent in familiar ones.

28 110 S Ct 1595 (1990). 
gious freedom. ${ }^{100}$ Instead, the majority claimed that the Court had "never held that an individual's religious beliefs excuse him from compliance with an otherwise valid law prohibiting conduct that the State is free to regulate."101 Since the only question was whether the state could regulate drug use generally-and who would say that it could not? - the majority did not even consider the case as presenting a threat to free exercise.

Smith exemplifies exception-barring because the majority based its rationale on a self-serving recharacterization of a long line of cases requiring exemptions from otherwise valid general state policies where those policies conflicted with religious beliefs. ${ }^{102}$ For example, in Wisconsin v Yoder ${ }^{103}$ the Court held that a state could not compel Amish children to attend school beyond the eighth grade, notwithstanding the indisputable validity of the state's compulsory education policy in general. The Court in Smith distinguished Yoder and the other cases by characterizing those cases as involving religion "in conjunction with other constitutional protections, such as freedom of speech and of the press, ... or the right of parents . . . to direct the education of their children."104 This characterization grossly misstates the rationale of Yoder, where the Court explicitly grounded its holding in the fact that there was no "state interest of sufficient magnitude to override the interest [claimed by the Amish] under the Free Exercise Clause." 105 Thus, as with all instances of exception-barring, one is left wondering what if anything remains of the principles announced in the prior cases.

This weakness of the exception-barring approach was summarized nicely by Justice O'Connor in her opinion in Smith. Although concurring in the judgment, she was harshly critical of the majority's rationale. Objecting to Justice Scalia's characterization of prior religion cases, she noted that the fact that the Court "re-

${ }^{100}$ But see id at 1606-15 (O'Connor concurring in the judgment) (disagreeing with the majority's analysis, but finding drug enforcement a sufficiently compelling interest to justify the burden).

101 Id at 1600.

102 See, for example, Pierce v Society of Sisters, 268 US 510 (1925) (finding parental right to private parochial education of their children); West Virginia State Board of Educ. $v$ Barnette, 319 US 624 (1943) (invalidating mandatory flag salute challenged by Jehovah's Witnesses); Wooley v Maynard, 430 US 705 (1977) (enjoining prosecution of Jehovah's Witnesses for covering up New Hampshire's motto of "Live Free or Die" on their automobile license plates).

108406 US 205 (1972).

$10410 \mathrm{~S} \mathrm{Ct}$ at 1601 (citations omitted).

${ }^{105} 406$ US at 214. 
jected the free exercise claims in those cases hardly calls into question the applicability of First Amendment doctrine in the first place. Indeed, it is surely unusual to judge the vitality of a constitutional doctrine by looking to the win-loss record of the plaintiffs who happen to come before" the Court. ${ }^{106}$ Justice O'Connor reminds us that the legal realist's effort to discern the law by looking not to what courts say but what they do may well be a valuable heuristic for predicting the outcome of any given case, but it is hardly an acceptable method for deciding cases.

Finally, we turn to Lakatos' preferred method for dealing with counterexamples: lemma-incorporation. Here the analogy between mathematics and law breaks down. Imagine that before the Court grants certiorari in the Hardwick case, Justices B and $\mathrm{W}$ are having a discussion. $\mathrm{B}$ contends that there is a fundamental right to control the nature of one's intimate associations. ${ }^{107} \mathrm{He}$ locates this right in the Court's prior privacy decisions. W claims that there is no such right, and offers homosexual sodomy as a counterexample to B's abstraction.

If $\mathrm{B}$ were a monster-barrer, he might declare homosexual sodomy a "crime not fit to be named," tion worth protection than rape ${ }^{109}$ or murder. If $B$ were an exception-barrer, he could contend that this is indeed an exception. Without reconsidering how he derived the right, he could recharacterize the liberty interest as a fundamental right to control one's intimate associations, except those involving homosexual sodomy.

$\mathrm{B}$, however, is a Lakatosian lemma-incorporator. Logic dictates that a counterexample to the main proposition is also a counterexample to at least one lemma. Because homosexual sodomy is an apparent counterexample to the main proposition that there is a fundamental right to control the nature of one's intimate associations, B must find the flawed lemma. Or must he? Doesn't $B$ have the additional option of denying that $W$ has found a counterexample to the main proposition? B could say that homosexual sodomy is in fact one of the intimate associations over which individuals have a fundamental right to exercise control. In

\footnotetext{
${ }^{108}$ Smith, $110 \mathrm{~S}$ Ct at 1610 (O'Connor concurring).

${ }^{107}$ See notes 54-56 and accompanying text.

${ }^{103}$ Hardwick, 478 US at 197 (Burger concurring) (quoting William Blackstone, 4 Commentaries *215).

${ }^{108}$ See id (remarking that Blackstone classified sodomy as "an offense of 'deeper malignity' than rape").
} 
that case, no lemma would be violated. This option is unavailable in mathematics. It is analogous to someone contending that the sum of the angles of any triangle on the surface of a sphere is in fact $180^{\circ}$.

Mathematicians cannot make such arguments because mathematics, by definition, proceeds from assumed unprovable postulates. Mathematicians do not argue about whether Euclid's Fifth Postulate is true in some metaphysical sense. They know that some conjectures will be provable if that postulate is assumed true and others will be provable if it is not. And that is about all there is to say in the realm of mathematics. ${ }^{110}$

By contrast, legal argument focuses on the truth or falsity of the preliminary assumptions. B will say to W: "I grant that if there is no right to homosexual sodomy then my articulation of the fundamental right to control the nature of one's intimate associations is in fact too abstract. But the whole question is whether there is such a right to homosexual sodomy." As noted in the discussion of the relationship between law and literature, logical consistency is too weak a condition to discriminate between competing abstractions. Law is, ultimately, unlike mathematics. ${ }^{111}$

\section{MichaEL $H$. AND THE VAIN QUEST FOR AN ALGORITHM OF ABSTRACTION}

We are now ready to evaluate Justice Scalia's proposal for avoiding value choices in selecting a level of generality. In Michael $H$. $v$ Gerald $D .,^{112}$ the Court upheld a California law denying parental rights to a man who claimed to be the biological father of a child born to a woman married to another man. In dissent, Justice

\footnotetext{
130 It is worth noting that this view of mathematics as a purely formal system whose postulates are neither true nor false in any deeply metaphysical a priori sense has not always prevailed. Immanuel Kant, for example, believed that Euclidean geometry "was inherent in the structure of the mind itself as a divinely implanted intuition." David M. Burton, The History of Mathematics: An Introduction 552 (Allyn \& Bacon, 1985). So dominant was Kant's view that even the great mathematician Carl Friedrich Gauss refused to challenge it publicly. In an 1824 letter to Franz Taurinus, Gauss wrote that "[t]he assumption that the sum of the three angles of a triangle is [not equal to] $180^{\circ}$ leads to a curious geometry, quite different from our own [the Euclidean], but thoroughly consistent, which I have developed to my satisfaction. ... In any case, consider this a private communication, of which no public use or use leading to publicity is to be made." Quoted in id at 550. See also Roger Penrose, The Emperor's New Mind (Oxford, 1989).

"11 Compare Laurence H. Tribe, Trial by Mathematics: Precision and Ritual in the Legal Process, 84 Harv L Rev 1329 (1971) (noting that law requires value judgments that are inherently non-quantifiable and not readily susceptible to accurate inclusion in a mathematical formula).
}

112109 S Ct 2333 (1989). 
Brennan argued that prior decisions recognized a fundamental liberty interest in the parent-child relationship. ${ }^{113}$ Writing for himself and Chief Justice Rehnquist, Justice Scalia dismissed Justice Brennan's choice of a level of abstraction as arbitrary:

We do not understand why, having rejected our focus upon the societal tradition regarding the natural father's rights visa-vis a child whose mother is married to another man, Justice Brennan would choose to focus instead upon "parenthood." Why should the relevant category not be even more general-perhaps "family relationships"; or "personal relationships"; or even "emotional attachments in general"? Though the dissent has no basis for the level of generality it would select, we do: We refer to the most specific level at which a relevant tradition protecting, or denying protection to, the asserted right can be identified. ${ }^{114}$

Justice Scalia's footnote 6, which Justices O'Connor and Kennedy pointedly declined to join and which seems destined to take its place among constitutional history's most provocative asides, recognizes the problem of abstraction and claims to solve it. This section argues that his claim fails on several grounds. First, the extraction of fundamental rights from societal traditions is no more value-neutral than the extraction of fundamental rights from legal precedent. Second, there is no universal metric of specificity against which to measure an asserted right. And finally, even if Justice Scalia's program were workable, it would achieve judicial neutrality by all but abdicating the judicial responsibility to protect individual rights.

Note first that when Justice Scalia refers to a tradition he means an historical tradition. Insofar as historical traditions are a source of values external to precedent, appeal to such traditions may provide the criteria for consistency that the precedents themselves do not provide. To use the chain novel metaphor, historical traditions are to be the criteria of fit. ${ }^{115}$

Justice Scalia is hardly the first to ground fundamental rights in historical tradition. Indeed, since justices generally do not assert but argue that they have expressed a fundamental right at the appropriate level of generality, they have looked to sources external

\footnotetext{
11 Id at 2352 (Brennan dissenting).

114 Id at 2344 n 6.

115 See text at notes 69-70.
} 
to their own value systems. And where better to look than historical tradition? ${ }^{116}$

It is worth noting that the law has never given its blessing to behavior simply because it is "traditional." If tradition sufficed, then the law would readily protect homosexuality, non-nuclear family arrangements, and any number of other behaviors that are widely practiced and longstanding. Legally cognizable "traditions" instead tend to mirror majoritarian, middle-class conventions. The Hardwick and Michael $H$. majorities so demonstrated, as did an earlier Court when it blithely declared polygamy "odious" to all but Mormons and "Asiatic and African people"117 - that is, to all but most of the world and the forebears of millions of Americans. The decision to look to tradition for guidance in defining fundamental rights therefore carries great risk. Judges must choose among competing traditions those which will receive legal protection-and the choice of, say, heterosexuality over homosexuality (or homophobia over tolerance) requires value judgments. If judges generally choose to enforce majoritarian values, then one cannot comfortably look to tradition to bolster the judicial role as protector of individual rights against the state.

Just as the choice of cognizable traditions involves value judgments, so does their description. What is novel about Justice Scalia's argument is the implicit suggestion that historical traditions come equipped with something like instruction manuals explaining how abstractly the Court should describe them. Yet surely historical traditions are susceptible to even greater manipulation than are legal precedents. But for Justice Scalia's suggestion to the contrary, Justice Brennan would have stated the obvious in observing that "reasonable people can disagree about the content of particular traditions."118

To acknowledge the manipulability of historical traditions is to recognize that all history is summary. The lens of the historical camera, in focusing on one event, necessarily blurs others. Take, for example, a question from outside the context of unenumerated fundamental rights that is still very much with us: does the Establishment Clause of the First Amendment embody a deeply rooted tradition of separation of church and state, one that bars religious

116 Compare Palko $v$ Connecticut, 302 US 319, 325 (1937) (asking if the putative right is "implicit in the concept of ordered liberty"), with Moore, 431 US at 503 (focusing instead on whether asserted liberties are "deeply rooted in this Nation's history and tradition").

117 Reynolds $v$ United States, 98 US 145, 164 (1879).

${ }^{118}$ Michael $H$., $109 \mathrm{~S} \mathrm{Ct}$ at 2349 (Brennan dissenting). 
displays from public property? ${ }^{118}$ To what sources should we look for the guiding historical tradition?

Focusing on positive law we would find that Massachusetts provided for local establishments as late as $1833 .{ }^{120}$ Virginia, on the other hand, enacted Jefferson's Enlightenment ideals even before the United States Constitution was written. ${ }^{121}$ At the level of positive law, then, traditions conflict. But if there were consensus among state legislatures, what would that prove? Does the emergence of minimum wage laws only in the late nineteenth century indicate a prior historical tradition recognizing a right to work for an arbitrarily small sum? The Lochner Court, if it spoke the language of fundamental rights and historical traditions, might have viewed the matter that way. But another interpretation is available. The late emergence of minimum wage laws corresponded with increasing industrialization; the formerly unnecessary became expedient. Before industrialization, legislators did not even think about minimum wages, much less decide that they violated a fundamental right. Thus, the absence of positive laws encroaching upon a right does not indicate the fundamentality of that right.

Conversely, the presence of positive laws encroaching upon a right does not negate the fundamentality of that right. If it did, then governments could violate constitutional norms by persisting in a pattern of unconstitutional enactments. However, "no one acquires a vested or protected right in violation of the Constitution by long use, even when that span of time covers our entire national existence and indeed predates it."122

Moreover, historical traditions, like rights themselves, exist at various levels of generality. Consider again the Virginia Bill for Religious Liberty. Although Jefferson's text resonates with the ideals of the Enlightenment, historians have shown that the primary political impetus behind the act's passage was a spirit of religious fervor, not enlightened ecumenicalism. Nonconformist religious fundamentalists in Virginia-who, contrary to the act's declaration

110 See, for example, County of Allegheny v ACLU, $109 \mathrm{~S} \mathrm{Ct} 3086$ (1989) (display of creche on public property violates Establishment Clause, but display of Christmas tree and menorah together does not); Lynch v Donnelly, 465 US 668 (1984) (ownership and erection of creche by city on non-city park does not violate Establishment Clause).

${ }^{120}$ See Tribe, American Constitutional Law $\$ 14-3$ at $1161 \mathrm{n} 25$ (cited in note 12) (state constitution authorized towns to hire ministers where voluntary contributions were inadequate).

${ }^{121}$ See Virginia Bill for Religious Liberty, described in Everson $v$ Board of Educ., 330

US 1, 11-13 (1947).

122 Walz v Tax Comm'n, 397 US 664, 678 (1970). 
otherwise, believed themselves infallible in ecclesiastical matters but lacked the numerical strength to establish their churches-decided that their own best hope for securing religious liberty lay in an alliance of convenience with the Jeffersonians. ${ }^{128}$ Thus, at the level of positive law there may be an historical tradition of religious toleration in Virginia, but at the level of social attitudes the existence of such a tradition is subject to doubt.

Late into the nineteenth century most Americans may well have believed that religion and politics should mix in "the 'sweet harmony' of a Christian nation,"124 thereby rejecting Jefferson's metaphorical wall of separation. This fact would be relevant to constitutional interpretation, but hardly dispositive. Unless we say that the Constitution is whatever the majority practices-and to say this much is to reduce the Constitution to a dead letter-we should not rule out the possibility that Jefferson was right about the meaning of the Establishment Clause and that his contemporary critics were wrong. ${ }^{125}$ Thus, history provides ambiguous guidance both because historical traditions can be indeterminate, and because even when we discover a clear historical tradition it is hardly obvious what the existence of that tradition tells us about the Constitution's meaning. Although we have illustrated this point with an example concerning the Establishment Clause, it applies equally to the project of deciding what rights are fundamental, and indeed to constitutional interpretation generally.

Justice Scalia understands how hard it is to distill many historical sources into a single judgment about what people thought about a particular institution or practice. In a recent article, he remarked that originalist jurisprudence is difficult to apply correctly because "the task requires the consideration of an enormous mass of material [and] immersing oneself in the political and intellectual atmosphere of the time-somehow placing out of mind knowledge that we have which an earlier age did not, and putting on beliefs, attitudes, philosophies, prejudices and loyalties that are not those of our day." 126 Justice Scalia nonetheless went on to

\footnotetext{
${ }^{123}$ For a discussion of the complicated relationship between anti-establishment theory and popular attitudes towards religious minorities during the decade preceding the American Revolution, see Bernard Bailyn, The Ideological Origins of the American Revolution 246-72 (Harvard, 1967).

124 William McLoughlin, Isaac Backus and the Separation of Church and State in America, 73 Am Hist Rev 1392, 1413 (1968).

${ }^{123}$ See id at 1400 (in the course of arguing that the predominant view was anti-Jeffersonian, acknowledging that Jefferson's secularism was "the more consistent position[]").

${ }^{126}$ Antonin Scalia, Originalism: The Lesser Evil, 57 U Cin L Rev 849, 856-57 (1989).
} 
state that he preferred the difficult originalist enterprise to subjective, and therefore illegitimate, non-originalist modes of constitutional interpretation. ${ }^{127}$ In response to our contention that historical traditions are generally ambiguous, Justice Scalia might argue that it is better to admit some ambiguity than to abandon the historical enterprise entirely.

This response completely fails to address a further weakness of the attempt to locate rights in historical traditions: how do we know when to reject an historical pattern or understanding? Justice Scalia remarked that "[e]ven if it could be demonstrated unequivocally that [public flogging and handbranding] were not cruel and unusual measures in 1791, [these practices] would not be sustained by our courts, and any espousal of originalism as a practical theory of exegesis must somehow come to terms with that reality." 128 Yet these remarks apply to any interpretive scheme that seeks to locate rights in the historical understanding of a prior age, the quest for "the most specific level" no less than originalism.

We turn now to a second weakness in the footnote 6 approach. What precisely is the "most specific level at which a relevant tradition" exists? Are positive laws more or less specific than social attitudes? Are social attitudes about one subject, say gender, more or less specific than social attitudes about another, such as religion? To paraphrase Justice Scalia's trenchant observation in another context, this exercise effectively asks "whether a particular line is longer than a particular rock is heavy." 129

The absence of a single dimension of specificity is a pervasive problem for the footnote 6 program. According to Justice Scalia, if "there were no societal tradition, either way, regarding the rights of the natural father of a child adulterously conceived, [the Court] would have to consult, and (if possible) reason from, the traditions regarding natural fathers in general."130 As Justice Scalia states the problem, after traditions regarding the rights of the natural father of a child adulterously conceived, traditions regarding natural fathers in general are the next most specific. But why must this be so? Why not abstract out the father's sex, and consult general traditions regarding parental rights of children adulterously conceived, and reason from these? Perhaps we can learn something

127 See id at 862.

${ }^{128}$ Id at 861.

129 Bendix Autolite Corp, v Midwest Enterprise, Inc., 468 US 888, 897 (1988) (Scalia concurring in the judgment).

${ }^{230}$ Michael H., $109 \mathrm{~S} \mathrm{Ct}$ at 2344 n 6. 
from the way the law treats natural mothers of adulterously conceived children. Or alternatively, why not abstract Gerald D. out of the case and consult traditions regarding unmarried fathers' rights in circumstances where the mother was not married to some other man at the time of conception? ${ }^{131}$ In other words, when we find no relevant tradition concerning asserted right $\mathrm{X}$ under conditions 1 and 2 , do we consult traditions concerning right $\mathrm{X}$ under condition 1 in general, or do we consult traditions concerning right $\mathrm{X}$ under condition 2 in general?

This is not a merely theoretical problem. In Roe, for example, the Court argued that there was no longstanding tradition making abortion illegal. ${ }^{132}$ In footnote 6 parlance, we might say that there is no dispositive tradition regarding the rights of a woman to control her reproductive freedom when that control means the destruction of a fetus. We would then have to look to the next most specific tradition. Is that a tradition regarding women's reproductive freedom in general? Or a tradition regarding behavior that affects fetuses, as reflected in laws making feticide a crime when caused by someone other than the mother? If the former, then the Court would ask if the fundamental right to privacy includes the right not to reproduce. Since Eisenstadt answered that question affirmatively, the Court might derive from this tradition a fundamental right to abortion. If the Court chooses traditions about feticide as the next most specific tradition, however, then it would have to hold that there is no fundamental right to abortion. Because Justice Scalia does not tell us how we are to measure the specificity of traditions, he cannot escape the value-laden choice of a level, and a direction, of abstraction.

Perhaps this difficulty arises only because we have concentrated on asserted rights for which there is no tradition on point. After all, in Michael $H$. Justice Scalia claimed that he could avoid searching for a next-most specific tradition because a specific tradition "unqualifiedly denie[d] protection" to "the natural father of a child adulterously conceived."13s

Even granting the existence of that "specific" tradition, however, it is not exactly on point. We can imagine, for example, a tradition regarding people who had conducted adulterous affairs similar to this plaintiff in various detailed respects or, for that

131 Both Justice Brennan and Justice White took this approach in their dissents in Michael $H$.

132410 US at $129-41$.

13s Michael H., 109 S Ct at 2344 n 6. 
matter, a tradition regarding people resembling this father in other ways that many would deem "obviously" irrelevant: hair color, race, age. Of course we do not expect to find such ridiculous traditions because a basic principle of our legal system is that such rules of law would be too specific, and therefore arbitrary. ${ }^{134}$ Yet, as with the non sequitur endings to Great Expectations, what counts as arbitrary is usually a matter of societal consensus rather than pure logic. Justice Scalia's formulation of the rights at stake as the rights of "the natural father of a child adulterously conceived" is therefore already a considerable abstraction. He has abstracted away lots of information that virtually everybody would agree is irrelevant. But he has also abstracted away some information that many people would see as quite relevant. The natural father in Michael $H$. had a longstanding, albeit adulterous and sporadic, relationship with the mother of his child. He also had fairly extensive, if sporadic, contact with his child. ${ }^{135}$ Surely this information is more significant than the plaintiff's race or age. A more specific formulation of the issue than Justice Scalia gives us would be: what are the rights of the natural father of a child conceived in an adulterous but longstanding relationship, where the father has played a major, if sporadic, role in the child's early development?

It is unlikely that any tradition addresses this very question at this precise level of specificity. Thus, we are left with the problem of specifying the next most specific tradition. Here, as in the abortion case, we find no single dimension or direction along which to measure the degree of abstraction or generality. Do we abstract away the father's relationship with his child and her mother, as Justice Scalia does? Or do we instead abstract away the fact that the relationship with the mother was an adulterous one, as Justice Brennan does? If we do the latter, then we will find ourselves consulting traditions regarding natural fathers who play major roles in their children's development. This sounds an awful lot like "traditions regarding natural fathers in general," which Justice Scalia regarded as less specific than his formulation of the problem. By starting from an even more specific description of the case than

\footnotetext{
${ }^{134}$ Nonetheless, even a glance at the Supreme Court's pronouncements about so-called "new rules" and their unavailability on federal habeas corpus to overturn state convictions, see Saffle v Parks, 110 S Ct 1257 (1990) (opinion by Justice Kennedy); Butler v McKellar, 110 S Ct 1212 (1990) (opinion by Chief Justice Rehnquist), will reveal that the current Court is alarmingly cavalier in its willingness to be ad hoc in the development and understanding of legal principles.

${ }^{135}$ Michael H., $109 \mathrm{~S} \mathrm{Ct}$ at 2337.
} 
did Justice Scalia, we have seen that he had no greater justification for abstracting away the father-child relationship than Justice Brennan had for abstracting away the adultery.

Justice Scalia is aware that the method of footnote 6 would severely curtail the Supreme Court's role in protecting individual liberties. Indeed, that seems to be his purpose. Concurring in Cruzan v Missouri Dept. of Health, ${ }^{136}$ he applied the Michael $H$. plurality opinion to conclude that "the federal courts have no business" pronouncing limits on state policies concerning the right to die. ${ }^{137}$ The Court in Cruzan upheld Missouri's rule requiring clear and convincing evidence of a patient's wish not to receive life-sustaining treatment for such treatment to be terminated. Because the Missouri courts had not found such clear and convincing evidence, the Court permitted the state to keep Nancy Cruzan "alive" in a vegetative state. In reaching that result, Chief Justice Rehnquist's majority opinion explicitly left open the possibility that a state rule requiring life-sustaining treatment despite a clear expression by the patient that she would not have wanted such treatment would violate the unenumerated constitutional right to die. ${ }^{138}$ And Justice O'Connor joined the majority opinion only on the express condition that it recognized such a right. ${ }^{138}$ Thus, adding her vote to those of the four dissenters, five justices in Cruzan read the Due Process Clause to protect the right to die. Depending upon how the other justices in the majority would treat the question the Chief Justice left open, there may be as many as eight votes for this right. Only Justice Scalia explicitly rejected a constitutional right to die. He argued that "even when it is demonstrated by clear and convincing evidence that a patient no longer wishes certain measures to be taken to preserve her life, it is up to the citizens of Missouri to decide, through their elected representatives, whether that wish will be honored."140

Justice Scalia concluded his Cruzan concurrence by suggesting that his unwillingness "to create out of nothing" rights under the Due Process Clause would not leave unenumerated individual rights unprotected against majority excesses. The Equal Protection Clause, he wrote, "is the source of most of our protection," because

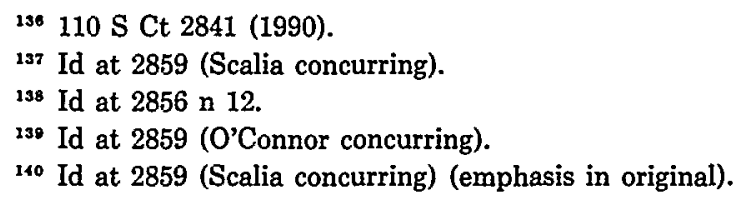


it "requires the democratic majority to accept for themselves and their loved ones what they impose on you and me."141

Perhaps Justice Scalia is correct then when he suggests that the citizenry does not need the Court's help in avoiding arbitrary impositions that harm everyone equally. But the Equal Protection Clause cannot necessarily protect unpopular liberties. Two simple illustrations will show that equal protection is a manifestly inadequate means of protecting many individual rights.

Consider a statute banning homosexual sodomy. Such a law would apply to all citizens, heterosexual as well as homosexual, and so in theory would impose the same constraint upon the democratic majority that enacted the law as it imposes on the minority who find that it curtails their liberty. Thus, under Justice Scalia's formulation, the law would be constitutional. Although Justice Scalia has twice voted to hold flag-burning protected by the First Amendment, ${ }^{142}$ the same would be true of a law banning flag-burning, since it would ban flag-burning by anyone. In this case the democratic majority proscribes an act that those in the majority have no intention of performing. Thus, such a law "imposes" nothing on the majority. The law imposes only on those in the minority who disagree with the policy that underlies it, for it is only their liberty that the law curtails in any meaningful sense.

Perhaps Justice Scalia has in mind a notion of equal protection that focuses not so much on the literal terms of a statute as on how it affects differently situated individuals. We might, for example, view a statute criminalizing homosexual sodomy as violating equal protection where the state does not also criminalize heterosexual vaginal intercourse. Similarly, we might view abortion prohibitions as denials of equal protection where the law does not also impose some analogous bodily burden upon men whenever conception occurs. However, to make such comparisons requires us to view the conduct proscribed at a fairly high level of generality. But at this point, the very historical traditions that lead Justice Scalia not to generalize for the purposes of the Due Process Clause would almost certainly prevent generalization under the Equal Protection Clause. As Justice Scalia apparently would use it, the Equal Protection Clause provides no greater protection for nontraditional liberties than does the Due Process Clause.

Progressive scholars, too, have attempted to substitute equal protection rationales for due process rationales, albeit with differ-

\footnotetext{
${ }^{141}$ Id at 2863.

${ }^{342}$ United States v Eichman, $110 \mathrm{~S} \mathrm{Ct} 2404$ (1990); Texas v Johnson, $109 \mathrm{~S} \mathrm{Ct} 2533$ (1989).
} 
ent goals from those of Justice Scalia. Thus, in an interesting effort to contain the Hardwick majority's effort to define rights narrowly and "conservatively," Cass Sunstein has advanced an argument to the effect that one might reconcile an anti-generalizing, traditionconserving approach to "liberty" with a more capacious and tradition-shattering approach to "equal protection."143 As a matter of advocacy and legal strategy, Sunstein's proposition may be a good one-although, like originalism itself, it founders on the shoals of Bolling $v$ Sharpe. ${ }^{144}$ As a matter of constitutional theory, the proposition seems somewhat dubious. It is hard to imagine a defensible approach to the two clauses that does not take greater account of the inseparability of liberty and equality.

Bolling is often remembered today as the case that introduced the so-called equal protection component of the Due Process Clause. But the Bolling Court did not rest its order to desegregate the District of Columbia's schools on an equal protection rationale. Instead, as Justice Souter noted in his recent confirmation hearings, the Court applied "the accepted kind of substantive due process that even the conservatives accept. And we're going to say is there at the present time a legitimate governmental objective which is being served by this particular restriction, i.e., the restriction on total freedom to attend [integrated] schools. And the most interesting thing about Bolling is that the Court said no, that [segregation] is not a legitimate government objective."145

We have argued that the footnote 6 program cannot succeed because it merely shifts the problem of abstraction from the realm of legal precedent to that of historical precedent, and because there is no such thing as a "most specific level" of generality. These problems seem inevitable, given Justice Scalia's vain quest for a value-free constitutional touchstone.

The footnote 6 approach is therefore doomed to fail, at least on its own terms. Nevertheless, one might argue that footnote 6 provides a valuable heuristic. Although it will not eliminate all aspects of judicial value choice, this argument would go, the footnote 6 program requires judges to make a serious effort to control their

${ }^{13}$ Cass R. Sunstein, Sexual Orientation and the Constitution: $A$ Note on the Relationship Between Due Process and Equal Protection, 55 U Chi L Rev 1161, 1170-78 (1988).

${ }^{14} 347$ US 497, 499-500 (1954) (relying on the "liberty" clause of the Fifth Amendment to invalidate public school segregation in the District of Columbia).

145 Nomination of Judge David Souter to be Associate Justice of the Supreme Court of the United States, Hearings Before the Senate Committee on the Judiciary (Sept 17, 1990) (unofficial transcript prepared by Federal News Service, available on Nexis computer service). 
own biases in specifying the level of generality of fundamental rights.

Although we agree that such an effort is vital, even this limited claim for the footnote 6 approach is insupportable. Because the footnote 6 program imports values surreptitiously-claiming all the while only to be discovering values that are out there in societal traditions-it enables judges to disguise and distort what is at stake. As Justice Brennan said of the doctrine of original intent, footnote 6 is "arrogance cloaked as humility." 146

To shed further light on how the footnote 6 methodology begs rather than addresses key constitutional questions, we examine another of Justice Scalia's footnotes in Michael H., footnote 4. Criticizing the Court's practice of first deciding whether a liberty is fundamental and then asking whether a government practice limiting that liberty can be justified, Justice Scalia stated for himself and three other members of the Court: "We cannot imagine what compels this strange procedure of looking at the act which is assertedly the subject of a liberty interest in isolation from its effect upon other people-rather like inquiring whether there is a liberty interest in firing a gun where the case at hand happens to involve its discharge into another person's body."147

Justice Scalia does not state an affirmative approach in footnote 4; on the surface he merely takes a potshot at Justice Brennan. From the footnote, however, one can fairly infer an approach to the definition of rights that is designed to overrule Roe. ${ }^{148} \mathrm{In}$ deed, it strongly echoes the position taken by Justice White, dissenting in Thornburgh $v$ American College of Obstetricians and Gynecologists. ${ }^{149}$ But the footnote 4 outlook has a far greater capacity: faithfully carried out, it could eliminate the use of the Due Process Clauses as guarantors of any fundamental liberties. When we automatically incorporate the factors that provide the state's possible justifications for its regulation into the initial definition of a liberty, the fundamental nature of that liberty nearly vanishes. Unless the state's interest is facially absurd, when it is suitably incorporated into an asserted liberty it will render that liberty so specific as to seem insupportable, or at least radically disconnected

\footnotetext{
${ }^{148}$ William J. Brennan, Jr., The Constitution of the United States: Contemporary Ratification, Address to Georgetown University Text and Teaching Symposium (October 12, 1985), reprinted in 19 UC Davis L Rev 2, 4 (1985).

${ }_{147} 109 \mathrm{~S} \mathrm{Ct}$ at $2342 \mathrm{n} 4$ (Scalia, joined by Rehnquist, O'Connor, and Kennedy).

148 For a fuller version of this argument, see Laurence H. Tribe, Abortion: The Clash of Absolutes 97 (Norton, 1990).

${ }^{148} 476$ US 747, 792 n 2 (1986) (White dissenting).
} 
from precedent. At a minimum, the privacy right protected in Roe becomes the implausible "right" to destroy a living fetus. If one takes footnote 4 to its logical limit in the interpretation of enumerated rights, ${ }^{150}$ then the free speech right protected in New York Times Co. $v$ Sullivan" ${ }^{151}$ becomes the dubious "right" to libel a public official, and the right to an exclusionary remedy protected in Mapp $v$ Ohio ${ }^{162}$ becomes the counter-intuitive "right" of a criminal to suppress the truth. To state these cases this way is to decide them in the government's favor. Anyone is free to argue that each of these cases was wrongly decided. But arguments to this effect must explain why the state interest overcomes the liberty interest. Under Justice Scalia's footnote 4 approach, by contrast, the state interest obliterates, without explanation and at the outset, any trace of the individual liberty at stake.

Nonetheless, one can read Justice Scalia's footnote 4 not as an end-run around strict scrutiny for fundamental rights, but as a plea for greater judicial flexibility. After all, there really is something artificial in the two-step process that the Court deploys in its fundamental rights cases, asking first whether the asserted liberty is fundamental, and only then asking if a compelling governmental interest outweighs the liberty. As Justice Stevens has observed in the equal protection context, the Supreme Court's "cases reflect a continuum of judgmental responses ... which have been explained in opinions by terms ranging from 'strict scrutiny' at one extreme to 'rational basis' at the other. ... . [but] these so called 'standards' [do not] adequately explain the decisional process."15s

Justice Stevens' point is that the degree to which a classification is suspect should depend on its purpose. For instance, gender should not be a suspect classification when used for segregating public rest rooms, but it should be suspect when used as a basis for denying job opportunities. By analogy, Justice Scalia's footnote 4 in Michael $H$. might be taken merely as a call for allowing legislatures greater flexibility in responding to the wide range of human needs. Thus, the right to make procreative decisions is arguably less fundamental when the decision involves external harms, such

150 Justice Scalia may have meant to limit the balancing approach of footnote 4 to the field of unenumerated rights, but he did not so specify, and as we have argued throughout this article, the questions that arise when one attempts to define unenumerated constitutional liberties also plague interpretation of enumerated rights.

152376 US 254 (1964).

162367 US 643 (1961).

${ }^{183}$ Cleburne v Cleburne Living Center, Inc., 473 US 432, 451 (1985) (Stevens concurring). 
as the destruction of a fetus. Perhaps Justice Scalia merely intended footnote 4 to replace the bifurcated fundamental rights inquiry with a sliding scale that weighs the individual's liberty interest against the state interest. If so, then it is a relatively harmless suggestion.

But the relationship of footnotes 4 and 6 illustrates the truly frightening potential of the approach that Justice Scalia's method, faithfully pursued, would entail. Footnote 6 instructs us to look for the most specific tradition we can find with respect to an asserted liberty interest. Although (as we believe we have shown) the concept of a most specific tradition is incoherent, footnote 4 suggests that Justice Scalia's program would have us start our search from a very specific liberty indeed-one that has the state interest built into it from the start. And it should also come as no surprise, as the examples that we have just given illustrate, that the "liberty" to frustrate various state policies cannot count as a liberty that is deeply rooted in our traditions.

It seems most unlikely that Justice Scalia would actually use his method to overrule virtually all of the Court's decisions protecting individual rights. More likely, it is a construct to be deployed selectively, allowing judges to define rights more or less abstractly depending upon their own views of how important those rights are, or of how they score on some other index every bit as extra-constitutional as the one that Justice Scalia accuses Justice Brennan of deploying. What Justice Scalia heralds as a means for assuring greater judicial objectivity is therefore quite the opposite.

\section{The Virtue of Consistency}

Justice Cardozo warned that a legal principle, once enunciated, will tend to expand to its logical limit, occupying fields for which it was not crafted. ${ }^{154}$ He perceived the danger that, in striving for a coherent and consistent body of law, we might so exalt abstract principles as to lose sight of common-sense notions of justice. But there is also virtue in consistency. Legal thought has everything to do with the evenhanded application of general principles to concrete situations. A prerequisite for the lawyer's art, therefore, is the enunciation of principles. A principle connects our intuitions about specific fact situations at a higher level of abstraction.

154 Benjamin N. Cardozo, The Nature of the Judicial Process 51 (Yale, 1921). 
The call for more abstract principles regarding the contours and contents of protected realms of liberty and equality, although dangerous in the way that Justice Cardozo warned, is on the whole a source of desirable pressure. Abstraction pushes us constantly to check practice against principle. Consider, for example, the promise contained in the Declaration of Independence that "all men are created equal." Suppose that the Declaration contained enforceable legal norms. A philosophy that refused to generalize would attempt to cabin this declaration: by "all men" the Continental Congress meant only propertied men, or only free men, or only white men, or only free white men with property. Each of these statements may be partly correct as a matter of historical truth. But we would argue, as have Ronald Dworkin and others, that the principle of equality, the abstraction of equality, became our constitutional legacy from our Revolutionary and, most significantly, our Civil War, forebears. ${ }^{155}$ The nation in which equality existed only as an abstraction was a nation, quite literally, at war with itself. The nation we are becoming may, we hope, be one in which equality is both generalized and concretized.

Perhaps in a perfect world, elected legislatures would accomplish the generalization of rights. But the Framers understood all too well that this is not a perfect world. ${ }^{156}$ Like it or not, judges must squarely face the task of deciding how abstractly to define our liberties. Requiring that fundamental rights be connected to the constitutional text provides one check on the tendency of judges to choose a level of abstraction to suit their own subjective preferences. This requirement provides a partial response to Judge Bork's charge that " $[t]$ here is no apparent reason why the Court should manipulate the level of generality to protect unconventional sexual behavior any more than liberty should be taken at a high

${ }^{15 s}$ See Ronald Dworkin, Law's Empire 387-89 (Harvard, 1986).

150 See, for example, Federalist 51 (Madison) in Edward Mead Earle, ed, The Federalist Papers 337 (Random House, 1937) ("If men were angels, no government would be necessary. If angels were to govern men, neither external nor internal controls on government would be necessary. In framing a government which is to be administered by men over men, the great difficulty lies in this: you must first enable the government to control the governed; and in the next place oblige it to control itself. A dependence on the people is, no doubt, the primary control on the government; but experience has taught mankind the necessity of auxiliary precautions."). Although the Federalists initially opposed the inclusion of a Bill of Rights in the Constitution, they became convinced that judicially enforceable rights are among the necessary "auxiliary precautions" against tyranny. See, for example, Letter from Thomas Jefferson to James Madison (March 15, 1789), in Adrienne Koch and William Peden, eds, The Life and Selected Writings of Thomas Jefferson 462 (Random House, 1944); Adrienne Koch, Jefferson and Madison: The Great Collaboration 58 (Oxford, 1964) (noting that Jefferson's letters strongly influenced Madison's proposed Bill of Rights). 
enough level of abstraction to protect kleptomania."157 The Constitution's repeated references to "property" pretty squarely foreclose any argument that there is a fundamental right to deprive another of her property.

By contrast, nothing in the Constitution's text remotely forecloses the argument that there is a fundamental right to control one's intimate associations, a right which encompasses unconventional sexual behavior. ${ }^{168}$ If we take seriously the Ninth Amendment's requirement that " $[t]$ he enumeration in the Constitution, of certain rights, shall not be construed to deny or disparage others retained by the people," at a minimum we must consider the possibility that rights which are consistent with the enumerated rights-as unconventional sexual behavior is and as kleptomania is not-may be protected by the Constitution. We are not suggesting that there are "Ninth Amendment rights" as such. Instead, we contend that the Ninth Amendment has some content. ${ }^{159}$

The Ninth Amendment is, by its terms, a rule of construction, indeed the only rule of construction in the Constitution. ${ }^{160}$ It tells judges, legislators, and other interpreters of the Constitution how not to "construe" that document. ${ }^{181}$ To make sense of the Ninth Amendment's proscriptive role, readers of the Constitution must assume that it also plays a prescriptive role. The Ninth Amendment counsels against the portrayal of enumerated rights as isolated islands of special protection, elevated above the surrounding sea of possible unenumerated rights "retained by the people," for to elevate the enumerated rights in this way would surely "disparage" those that remain underwater. If the Ninth Amendment condemns such a vision, then it must condone the opposite vision elaborated by Justice Harlan in his Poe dissent. The Ninth

167 Bork, The Tempting of America at 204 (cited in note 14).

${ }^{158}$ See Hardwick, 478 US at 196 (Burger concurring) (instead, attributing significance to the fact that the asserted right conflicts with the "Judeo-Christian moral and ethical standards").

${ }^{159}$ But see Thomas B. McAffee, The Original Meaning of the Ninth Amendment, 90 Colum L Rev 1215, 1309 (1990) ("There is no reason to think that the amendment's language, read in historical context, strengthens the argument for unwritten affirmative rights derived from constitutional structure.").

${ }^{160}$ See Laurence H. Tribe, On Reading the Constitution, 1988 Utah L Rev 747, 789.

${ }_{161}$ See Ackerman, 99 Yale L J at 1430 (cited in note 67) (observing that the Ninth Amendment "seems, almost preternaturally, to be written with [Bork] in mind"). Justice Scalia did concede the existence of the Ninth Amendment at his confirmation hearings ("I have one here, too," he advised Senator Biden as they compared copies of the Bill of Rights) but has not depended on it as a rule of construction. Nomination of Judge Antonin Scalia to be Associate Justice of the Supreme Court of the United States, Hearings Before the Senate Committee on the Judiciary, 99th Cong, 2d Sess 103 (1986). 
Amendment thereby affirmatively acts as a presumption in favor of generalizing at higher levels of abstraction. Charles Black's critique of those who would read the Ninth Amendment out of the Constitution seems particularly appropriate here. Black noted that "a corpus juris of human rights . . . will never be built; it will always be building, like the common law. If this method [of generalizing rights] is not rational, then neither is the common law. And neither is any other attempt to give due effect to similarities and differences between already decided and newly presented cases and problems."162

Justice Brennan's eloquent dissent in Michael $H$. echoed Black's dynamic view of the process of defining constitutional rights. Justice Brennan wrote that the Constitution as the Michael $H$. plurality construed it "is not the living charter that I have taken to be our Constitution; it is instead a stagnant, archaic, hidebound document steeped in the prejudices and superstitions of a time long past."18s The notion of a living Constitution-which is one of the many contributions that have earned Justice Brennan his place as one of the most influential Supreme Court justices in our history-might seem to be at odds with an approach to fundamental rights that looks to historical traditions. But if we accept the invitations from both Professor Black and Justice Harlan to seek rational unifying principles, we will see that it is not.

A proponent of a living Constitution would be subject to the charge of unbridled result-orientation if the entire meaning of that concept were that the Supreme Court's proper function is to update the Constitution periodically to keep it in tune with the times. ${ }^{164}$ However, the method of the common law can constrain a justice interpreting a living Constitution. When faced with a case of first impression, a judge schooled in the common law attempts to draw principled distinctions among the prior cases. This method should also apply to interpreting historical traditions. Thus, in a case like Hardwick, the Court should have asked what justification existed for treating the traditions regarding respect for intimate personal associations as inapplicable to gay intimacy. And in a case like Michael $H$., the Court should have required some principled reason for not applying general traditions (and cases) regarding

\footnotetext{
${ }^{162}$ Charles L. Black, Jr., "On Reading and Using the Ninth Amendment," in The Humane Imagination 194 (Ox Bow, 1986).

${ }^{163}$ Michael H., $109 \mathrm{~S} \mathrm{Ct}$ at 2351 (Brennan dissenting).

184 William H. Rehnquist, The Notion of a Living Constitution, 54 Tex L Rev 693 (1976).
} 
natural fathers to Michael $\mathrm{H}$. The justification offered by the plurality-the state's interest in preserving the "unitary family"165_begs rather than answers the relevant question. Why should the family relationships worthy of protection not include someone in Michael H.'s position vis-a-vis his daughter? The Ninth Amendment, in our view, places the justificatory burden on those who would deny the existence of a given right. That burden was not met in Michael $H$.

Our approach to defining fundamental rights places precedent and historical tradition on a more or less equal footing. The Ninth Amendment's presumption in favor of generalizing rights applies to the interpretation of cases and traditions. Apparently, the footnote 6 program also treats precedent and tradition according to a single framework, although it engages in the opposite presumption. Dissenting in Michael $H$., Justice Brennan and Justice White (whose dissent Justice Brennan joined) both severely criticized the plurality opinion for ignoring the Court's precedents regarding the rights of unwed natural fathers. ${ }^{166}$ For Justice Scalia, of course, the prior cases were irrelevant because they did not concern an unwed father in circumstances where the mother was married to someone else when the child was conceived. ${ }^{167}$ In this regard, Justice Scalia's approach to precedent in Michael $H$. is identical to his approach to historical traditions: he describes prior cases, like historical traditions, in what he deems the narrowest possible terms. And why not? Supreme Court precedents form a subset of the "relevant tradition[s] protecting or denying protection to the asserted right."168 Although the rationale for footnote 6 applies equally to prior cases and historical traditions, Justice Scalia has at least on one occasion criticized other members of the Court for failing to describe prior cases at a high enough level of generality. ${ }^{168}$ Although we recognize

${ }^{16 s}$ Michael $H$, $109 \mathrm{~S} \mathrm{Ct}$ at 2342.

${ }^{166}$ As both dissents noted, the plurality misread four cases: Stanley v Illinois, 405 US 645 (1972); Quilloin v Walcott, 434 US 246 (1978); Caban v Mohammed, 441 US 380 (1979); and Lehr $v$ Robertson, 463 US 248 (1983). "The basic principle enunciated in [these] cases is that an unwed father who has demonstrated a sufficient commitment to his paternity by way of personal, financial, or custodial responsibilities has a protected liberty interest in a relationship with his child." Michael $H$., $109 \mathrm{~S} \mathrm{Ct}$ at 2360 (White dissenting). See also id at 2352 (Brennan dissenting).

${ }_{16 z}$ Id at 2344 (plurality "not aware of a single case, old or new," awarding parental rights to the father of a child born of an adulterous relationship).

${ }^{168}$ Id at $\mathrm{n} 6$.

169 Webster $v$ Reproductive Health Services, 109 S Ct 3040, 3065 (1989) (Scalia concurring in part and concurring in the judgment) (chastising the Court for its failure to announce "a [new] rule of constitutional law" not required by the facts of the case). 
that Justice Scalia may have some unarticulated reason for believing that the footnote 6 methodology does not apply to characterizing prior cases, throughout the remainder of this article we assume, based upon his treatment of the prior cases in Michael H., that it does so apply.

As we have noted, the requirement that distinctions among prior cases and historical traditions be principled provides one check on result-orientation. Result-orientation would be further limited by a requirement that the asserted level of generality provide an appropriate description of already-protected rights without reference to the newly asserted rights. ${ }^{170}$ Judges should ask whether the abstraction is a bona fide tradition or "a mere concoction for litigational purposes."171 First, the Court must determine what concerns actually motivated the prior decisions. Only after the Court has selected the appropriate level of abstraction at which to describe these concerns should it test the asserted specific right against that abstraction. ${ }^{172}$

This program does not eliminate judicial value-choice, but it does limit choice considerably more than does the footnote 6 program. It does so by requiring that, in characterizing its prior cases, the Court look not only to what those cases held, but also to the essential reasons for those holdings. To borrow from Lakatos' model of mathematical proof, judges should avoid exception-barring. ${ }^{173}$ Just as a mathematician attempts to preserve not only the proposition but also its proof, so a judge should preserve not only the holding of a prior case but also its rationale. An abstraction that has been concocted merely for litigational purposes will often be recognizable as such because it is consistent with only the holdings of prior cases, not their rationales.

The anti-generalizing approach exemplified by footnote 6 of Michael $H$., by contrast, is a form of judicial nihilism. It denies that there are essential aspects to prior cases. By suggesting that only specific historical traditions can fix the appropriate level of generality at which to define rights, Justice Scalia apparently assumes that there is no way to read the prior cases on their own terms and discern the level of generality at which a right was rec-

${ }^{170}$ Laurence H. Tribe, American Constitutional Law 946 (Foundation, 1978).

171 Id.

172 Justice Brennan's dissent in Michael $H$. proceeds much along these lines, first arguing that the prior cases support a right to parenthood that is broader than the "unitary family," $109 \mathrm{~S} \mathrm{Ct}$ at 2353, and only then locating the specific right within the general description. Id at 2355-59.

${ }^{173}$ See text at notes 95-106. 
ognized. This assumption by Justice Scalia is impossible to square with much of what we ordinarily think the judicial enterprise entails. $^{174}$

To see the advantage of our approach, consider a hypothetical question that a law professor might pose to her students: would Griswold have come out the other way if it had involved abortion, that is, if it had concerned not the right to have sex without conception occurring, but the right to have sex without bearing a child notwithstanding the fact that conception did occur? The purpose of the law professor's question would be to test the limits of the Court's reasoning. Ordinarily, we would expect the students to marshal various arguments explaining why the fact that conception had not yet occurred in Griswold was or was not essential to the case. We are imagining that Roe has not yet been decided, or that the students have not yet studied it.

Those students who believed that the timing of the decision not to bear a child was essential to Griswold could point to the majority's references to the inviolability of the home through its invocation of the Third and Fourth Amendments, and its rhetorical question: "Would we allow the police to search the sacred precincts of marital bedrooms for telltale signs of the use of contraceptives?"175 Thus, they could argue, Griswold turns on the fact that the Connecticut ban on contraceptive use applied to an activity in the home, whereas women generally have abortions in a hospital, a clinic, or some other medical facility.

The students who believed that a right broad enough to include abortion was essential to Griswold would argue that the principal focus of the Griswold opinion was the marriage relationship. They would note that a state prohibition on such decisions would have no less "destructive impact"176 upon the relationship of a husband and wife than the Connecticut law had upon the relationship of a husband and wife who wished to use contraceptives. ${ }^{177}$

${ }^{174}$ Indeed, Justice Scalia's apparent lack of faith in judges' ability to assimilate the essential messages of prior opinions is also inconsistent with his own belief that in making sense of other kinds of texts, such as regulations, statutes, and the Constitution, the judge's principal role is linguistic analysis. See, for example, Maryland v Craig, $110 \mathrm{~S} \mathrm{Ct} \mathrm{3157,3171}$ (1990) (Scalia dissenting) (closed-circuit testimony of child abuse victims, outside defendant's presence, violates "categorical guarantee" of the Confrontation Clause). See also George Kannar, The Constitutional Catechism of Antonin Scalia, 99 Yale L J 1297, 1343 (1990) (describing Justice Scalia's approach to constitutional interpretation as "textualist formalism").

175381 US at 485.

$178 \mathrm{Id}$.

${ }^{177}$ The students could correctly point to many references to marriage in Griswold's 
As in most law school discussions, there may be no "correct" answer to this hard question. If we attempt to place each fact of Griswold on one of two lists, one containing essential facts and the other containing nonessential facts, we will find that reasonable people can disagree over where some facts belong. However, there will be widespread agreement over many others. For instance, nearly everyone would agree that the race of the parties belongs on the nonessential list, while the fact that the case involves an intimate act belongs on the essential list. As with so many legal questions, the interesting argument over what constitutes an essential fact will concern how and where to draw lines.

Now imagine how the discussion would differ in a law school in which the footnote 6 approach prevails with respect to reading cases as well as historical traditions. Since footnote 6 commands that we consult the most specific tradition that governs the very facts presented by the case, it offers no way to determine what facts may be abstracted away. We cannot discuss how a case differs when one fact is changed. We cannot say how Griswold would have differed if it had involved the right to bear a child, notwithstanding that conception has occurred, any more than we can say how Griswold would have differed if it had involved a completely different subject, such as the right to drive without a seatbelt.

Yet surely there is a qualitative difference between these two variations on the facts of Griswold. In the former example we have abstracted away a fact that.may or may not be important, and our discussion will focus on whether we should deem that fact important. But in the latter example we have abstracted away the whole case. Had Griswold involved the right to abortion, it might have come out differently, but if it had involved the right to drive without a seatbelt it would not even have been Griswold. It would have been some other case.

Of course, a truly radical anti-generalizer could respond that Griswold would be a different case if we change any fact at all. If we were philosophers of language, this response might spark an interesting debate. Some philosophers have taken the position that there is nothing essential to an object beyond some list of proper-

majority and concurring opinions, but they would have no monopoly on interpretation of these references. Charles Fried, arguing the Webster case before the Supreme Court for the United States as amicus curiae, cited Griswold for the proposition that there is a "right not to have the state intrude ... in a very violent way ... into the details of marital intimacy." Oral Argument Transcript at 21. This right of marital intimacy, in Fried's formulation, did not encompass a right to terminate a pregnancy conceived in the marital bedroom. 
ties that we define as essential to it. ${ }^{178}$ Others, like Saul Kripke, have criticized this view, noting that people ordinarily speak as if there is a difference between necessary and contingent properties of various objects or persons. ${ }^{179}$ For instance, although we may have a difficult time formulating complete lists of the essential and non-essential properties of Richard Nixon (or "Nixonhood"), we can make a pretty good guess as to how to classify many properties. Because we can make sense of the question, "what would the world have been like if Nixon had lost the 1968 Presidential election?" we can say that "winning in 1968" is not an essential property of Nixonhood. By contrast, a question like "what if Nixon were a moose?" is meaningless because it is impossible for us to conceive of Nixon as being a moose and yet still being Nixon. "Being a human being," or at least "not being a moose," is an essential property of Nixonhood. ${ }^{180}$

There may well be philosophical objections to a theory of essential properties that proceeds along the lines of these examples. As a practical matter, however, law must proceed from the assumption that judges can tell the difference between the essential and the trivial in reading and applying prior decisions. Recognizing such distinctions in a principled manner is, after all, the essence of legal judgment. ${ }^{181}$

\section{Conclusion}

We have argued that judges possess the requisite tools to make principled distinctions in the selection of a level of generality in defining fundamental rights. A too-abstract right will be recognizable as such whenever its enunciation requires us to virtually ignore the rationales of the cases which allegedly established it. Thus, for example, someone who attempted to extend the privacy cases to include the specific right of one consenting adult to sell narcotic drugs to another based upon a general right of consenting adults "to do whatever they please so long as they directly injure no innocent bystanders," would have to ignore much of the lan-

${ }^{178}$ See Gottlob Frege, "On Sense and Nominatum," in Herbert Feigl and Wilfrid Sellars, Readings in Philosophical Analysis 86 (Appleton-Century-Crofts, 1949); Wittgenstein, Philosophical Investigations $\$ 79$ (cited in note 73).

179 See Saul A. Kripke, Naming and Necessity (Harvard, 1980).

180 See id at 38-70.

${ }^{182}$ Compare Note, Justice Stevens' Equal Protection Jurisprudence, 100 Harv L Rev 1146, 1156-58 (1987) (observing that, although discriminatory race-based practices and affirmative action programs present formally identical issues, judges should pay attention to the important practical distinction). 
guage in those cases making clear that only certain decisions are fundamentally private in character because " $a$ certain private sphere of individual liberty will be kept largely beyond the reach of government." ${ }^{82}$ The clear implication of this language is that some aspects of liberty are not fundamental. Just as the Constitution's repeated references to private property render fatuous any asserted right to steal, so the concern for the preservation of human life expressed in both the Fifth and Fourteenth Amendments undercuts a fundamental liberty interest in assisting an otherwise healthy individual to poison herself.

No doubt the boundaries of the "certain private sphere" are difficult to ascertain and are fluid through time. ${ }^{183}$ Yet to marshal this uncertainty in support of a jurisprudence that allows traditions of intolerance forever to insulate intrusive government activities from constitutional scrutiny is to question much more than the enterprise of fundamental rights: it is to question law itself.

The better approach would be to follow Professor Black's advice that we build "a corpus juris of human rights" by the method of the common law. And when choosing constitutional tools with which to build, we must resist the invitations of both conservatives and liberals to shy away from the Due Process Clauses. As Justice Souter noted in his insightful testimony on Bolling, those clauses provide an essential link between constitutional liberties and fundamental notions of fairness and equality.

The basic choice-and neither the Constitution's text nor its structure nor its history can make it for us-is between emphasizing the "conservative" functions of both the liberty and equality clauses (as well as others), and emphasizing their potential as generators of critique and change. We must justify the choice extratextually, but we may and should then implement it in ways that draw as much guidance as possible from the text itself. Justice Harlan exemplified such a program in his Poe dissent, in which he opted for a moderately conservative orientation toward generalization (one considerably less tradition-conserving than Justice Scalia's, however) and sought unifying structures for specified rights in an intermediate level of generality, drawing heavily upon textual points of reference.

182 Thornburgh, 476 US at 772 (emphasis added).

${ }^{183}$ See Louis Michael Seidman, Public Principle and Private Choice: The Uneasy Case for a Boundary Maintenance Theory of Constitutional Law, 96 Yale L J 1006, 1042-46 (1987). 
In the Hardwick context, if one is willing to generalize much at all, the Constitution's text-in the First Amendment's protection of peaceful assembly and in the Fourth Amendment's protection of the home-points toward generalizing in the direction of intimate personal association in the privacy of the home rather than generalizing in the direction of, let us say, freedom of choice in matters of procreation. It is for this reason that Hardwick seems to us so egregiously wrong; that Roe seems a closer and more difficult case; that a supposed "fundamental right" to use a sperm bank would represent a particularly bold leap; and that a "right" to enforce a surrogacy contract against a woman who has changed her mind and wishes to keep her gestational child entails a leap across a constitutionally unbridgeable void. 